\title{
Integrated quadratic assignment and continuous facility layout problem
}

\author{
Kamran Forghani, Alireza Arshadi khamseh ${ }^{*}$ and Mohammad Mohammadi
}

Department of Industrial Engineering, Faculty of Engineering, Kharazmi University, Karaj, Iran

\begin{tabular}{|c|c|}
\hline ART ICLE I NFO & A B S T R A C T \\
\hline $\begin{array}{l}\text { Article history: } \\
\text { Received 12 April } 2012 \\
\text { Received in revised format } \\
\text { 5 July } 2012 \\
\text { Accepted July } 62012 \\
\text { Available online } \\
\text { 8 July } 2012 \\
\text { Keywords: } \\
\text { Integrated facility layout problem } \\
\text { Quadratic assignment problem } \\
\text { Mathematical programming } \\
\text { Heuristic method }\end{array}$ & $\begin{array}{l}\text { In this paper, an integrated layout model has been considered to incorporate intra and inter- } \\
\text { department layout. In the proposed model, the arrangement of facilities within the departments is } \\
\text { obtained through the QAP and from the other side the continuous layout problem is implemented } \\
\text { to find the position and orientation of rectangular shape departments on the planar area. First, a } \\
\text { modified version of QAP with fewer binary variables is presented. Afterward the integrated } \\
\text { model is formulated based on the developed QAP. In order to evaluate material handling cost } \\
\text { precisely, the actual position of machines within the departments (instead of center of } \\
\text { departments) is considered. Moreover, other design factors such as aisle distance, single or multi } \\
\text { row intra-department layout and orientation of departments have been considered. The } \\
\text { mathematical model is formulated as mixed-integer programming (MIP) to minimize total } \\
\text { material handling cost. Also due to the complexity of integrated model a heuristic method has } \\
\text { been developed to solve large scale problems in a reasonable computational time. Finally, several } \\
\text { illustrative numerical examples are selected from the literature to test the model and evaluate the } \\
\text { heuristic. }\end{array}$ \\
\hline
\end{tabular}

\section{Introduction}

Facility layout is an important and complex problem for today's manufacturing systems. A facility layout problem (FLP) is about arranging physical departments and facilities within a manufacturing or service systems. The most commonly considered criterion in developing a FLP is to minimize total material handling distance/cost (Heragu \& Kusiak, 1988). According to Tompkins et al. (2003), between $20 \%$ and $50 \%$ of total operating expenses within manufacturing is attributed to material handling. In a manufacturing system, the material handling function includes transportation of work-inprocess (WIP), finished parts, materials and tools between machines or workstations. An efficient layout contributes to reduce production cycles, WIP, Idle times, number of bottlenecks or material handling times and the increase in the production output and productivity (Sule, 1994).

The FLP has attracted extensive attention from industry and academia in last decades. Researches: Kusiak and Heragu (1987), Meller and Gau (1996), Singh and Sharma (2005) and Drira et al. (2007) summarized detailed review, different modeling and solution procedures to the FLP. Due to the * Corresponding author.

E-mail: arshadi.kh@tmu.ac.ir (A. Arshadi khamseh)

(C) 2012 Growing Science Ltd. All rights reserved. doi: $10.5267 / j$. ijiec.2012.07.001 
complexity of the problem only limited number of papers have addressed exact solution methods for the FLP; however, the majority of work on the FLP has focused on heuristic and meta heuristic approaches to find good solutions.

In the FLP, it is assumed that the areas of the departments are known, although the exact department shapes are typically not specified in advance. However, it is commonly assumed that departments will take rectangular shapes. The final solution of the layout problem is a block layout that shows the coordinate information including the dimensions and location of each department. Heragu \& Kusiak (1991) developed a special case of the FLP, where the length, width, and orientation of the department are known in advance. Exact solution methods based on MIP up to now cannot solve large FLP problems (more than nine departments) in a reasonable time (Konak et al., 2006). From the other side, the QAP can solve the larger size problems, by assuming that all departments are equal-sized and must be allocated to the predetermined locations (candidate points), nevertheless QAP cannot solve large scale problems optimally in a polynomial time when the departments size is above 15 facilities. It is possible to model unequal area departments in the QAP formulation by breaking the departments into small grids with equal areas and assigning large artificial flows among them to prevent the separation of grids of the same department (Kaku et al., 1988; Kusiak \& Heragu, 1987; Kochhar et al., 1998). However, this significantly increases the number of integer variables in the formulation so that solving even small problems becomes difficult.

The design of an efficient manufacturing system must take into account a number of issues including the determination of the products to be manufactured, the manufacturing or service processes to be used, the quantity and type of equipment required, and the preliminary process plans. In practice, due to the complicated nature of the integrated problem, these decisions are taken by breaking the main problem into several sub problems and considering interaction among them. For instance, according to Wemmerlöv \& Hyer (1986), the design of a cellular manufacturing system (CMS) includes (1) cell formation (CF) - grouping parts with similar design features or processing requirements into part families and associated machines into machine cells, (2) group layout - layout machines within each cell (intra-cell layout) and cells with respect to another (inter-cell layout), (3) group scheduling scheduling parts and part families for production, and (4) resource allocation - assigning tools and human and materials resources.

Layout types used in manufacturing systems can be classified as process layout, product layout, cellular layout (GT), fixed-position layout, hybrid layout, etc. In these layout types, facilities can be arranged in different shapes such as single-row, multi-row, circular, U-shape, etc. However, enforcement of facilities to get arranged in a pre-specified layout shape may increase the total distance traveled by the materials (Solimanpur et al., 2005). In most of mentioned layout types, especially process layout and cellular layout, the layout problem is an essential part of production process design, but mostly due to overwhelming complexity in the nature of these problems, layout problem is studied as a separate part. Hicks (2006) presented a layout design tool based on genetic algorithm (GA), which can be applied to cellular or non-cellular facilities. They tested the proposed tool using case study from a collaborating capital goods company and concluded that when the layout is considered as brown-field problem there is a reduction of total rectilinear distance travelled of $25 \%$ compared to the company's layout, while when the layout is treated as a green-field problem, the total rectilinear distance travelled is reduced by 70\%. Tavakkoli-Moghaddam et al. (2007) developed a new mathematical model to solve a facility layout problem in CMSs with stochastic demands. They assumed that both machines and cells (departments) are equal-sized and used an integrated assignment model to allocate cells and machines to predefined locations on how total costs of inter and intra-cell movements can be minimized. Finally, they realized that depending on the attitude of the decision maker towards uncertainty, the optimal layout can be changed significantly. Chan et al. (2006) presented a two-stage approach for solving CF problem as well as cell layout problem, where the first stage is to identify machine cells and part 
families and the second stage is to find the linear arrangement of the machine cells as a QAP in order to minimize intercellular movement distance unit. They employed GA to solve the problem.

There are some efforts in the literature that consider the layout problem with other design factors, simultaneously (see Akturk \& Turkcan, 2000; Chiang \& Lee, 2004; Wu et al., 2007; Taghavi \& Murat, 2011). However, in order to handle the complexity of the problem, the authors have to apply some unrealistic assumptions such as: enforcement facilities to get arranged in linear layout, minimization of total number of inter-department (inter-cell) movements due to the exceptional elements in the CMS approach instead of actual inter-department material handling cost, fixed position of departments, equal-sized departments, etc.

Briefly, the traditional models of facility layout design in manufacturing systems, which result in a block diagram, departments (cells) sequence and linear arrangement of facilities, have limitations in revealing the information necessary for designing manufacturing facilities. Therefore, exploration of integrated layout model that concurrently determines intra and inter-department layout is necessary. To fill this gap, in this paper an integrated layout problem will be developed, that incorporates intra and inter-department layout.

In the proposed model the arrangement of facilities within the departments is obtained through the QAP and from the other side, the continuous layout problem is implemented to find the position and orientation of rectangular shape departments on the planar area. In fact in the proposed model the speed of QAP in department level is combined to the flexibility and accuracy of continuous layout in plant floor level. In order to evaluate material handling cost precisely the actual position of machines within the departments (instead of center of departments) is considered. Moreover other design factors such as aisle distance, single or multi row inter department layout and orientation of departments have been considered. Before formulating the integrated model, a modified version of QAP, with fewer binary variables and under conditions is developed (this model can solve small and small-to-medium scale problems in a shorter computational time). Then the integrated model is formulated based on the developed QAP in order to minimize total inter and intra-department material handling cost. In addition, a heuristic algorithm has been proposed to solve large-scale problems in a reasonable computational time. One of the applications of proposed model is in layout design of CMS. Therefore, several illustrative numerical examples are selected from the literature of CMS in order to test the proposed model and evaluate the performance of heuristic method.

\section{A new formulation on the QAP}

In this section, a modified version of QAP is presented in order to solve small and small-to-medium scale problems in a shorter computational time. The QAP was originally introduced by Koopmans \& Beckmann (1957), and generally defined as assignment of $\mathrm{M}$ facilities to $\mathrm{N}$ candidate points (Fig. 1.a) by minimizing total material handling cost. In this paper, it has been assumed that each department is divided into candidate points, where facilities must be assigned to them, therefore we have a QAP in each department. In the modeling of the QAP, a set of binary variables $\left(z_{i j}\right)$ is used to assign the facilities to the candidate points (if $z_{i j}=1$ then facilityiis assigned to candidate point $j$, and $z_{i j}=0$ otherwise).The QAP can be formulated as the following integer program with quadratic objective function:

QAP: $\min \sum_{i} \sum_{k>i} \sum_{j} \sum_{l} c_{i k} \cdot f_{i k} \cdot d_{j l} \cdot z_{i j} \cdot z_{k l}$

subject to:

$\sum_{i} z_{i j}=1, \quad \forall j$ 
$\sum_{j} z_{i j} \leq 1, \quad \forall i$,

$z_{i j} \in\{0,1\}, \quad \forall i, j$,

where $c_{i k}$ is material flow cost per unit distance between facility $i$ and $k, f_{i k}$ is material flow between facility $i$ and $k$, and $d_{j l}$ is distance between candidate point $j$ and $l$.

Objective function (1) minimizes the total material handling cost, constraint (2) ensures that each facility is assigned to only one candidate point and constraint (3) assures that each candidate point is occupied by utmost one facility.

There are three main methods used to find the global optimal solution for a given QAP: dynamic programming, cutting plane techniques, and branch and bound procedures. Research has shown that the latter is the most successful for solving instances of the QAP (Commander, 2003).The first attempts to solve the QAP eliminated the quadratic term in the objective function (i.e. $z_{i j} . z_{k l}$ ), in order to transform the problem into a MIP. The linearization of the objective function is usually achieved by introducing new variables and new linear (and binary) constraints. Here a method from Kaufmann and Broeckx (1978) which has the smallest number of variables and constraints is applied to linearize the QAP. They rearranged objective function (1) to the following expression: $\sum_{i} \sum_{k>i} z_{i j} \sum_{j} \sum_{l} c_{i k} \cdot f_{i k} \cdot d_{j l} \cdot z_{k l}$, then they defined new positive variable as follows: $w_{i j}=z_{i j} \sum_{j} \sum_{l} c_{i k} \cdot f_{i k} \cdot d_{j l} \cdot z_{k l}$ and showed that the QAP is equivalent to the following MIP:

QAP: $\operatorname{Min} \sum_{i} \sum_{j} w_{i j}$

subject to: (2)-(4)

$\sum_{k>i} \sum_{l} c_{i j} \cdot f_{i j} \cdot d_{j l} \cdot z_{k l}-w_{i j} \leq\left(1-z_{i j}\right) \sum_{k>i} \sum_{l} c_{i j} \cdot f_{i j} \cdot d_{j l}, \quad \forall i, j$,

$w_{i j} \geq 0, \quad \forall i, j$,

Sahni and Gonzalez (1976) proved that the QAP belongs to the class of computationally hard problems known as NP-complete (i.e. there is no algorithm which can solve the QAP to optimality in polynomial time), and the problems of size greater than 15 facilities remain nearly intractable.

In order to decrease the number of binary variables, it is assumed that candidate points have been composed of pre-specified columns and rows, such as a grid (see Fig.1.b, there is 4 columns and 3 rows with 12 candidate points), also following conditions must be met:

I. Widths of all rows in column $m$ are equal

II. Heights of all columns in rown are equal

To formulate the problem two sets of binary variables $z_{i m}^{X}$ and $z_{i m}^{Y}$ are used to assign the facilities to the candidate points where $z_{i m}^{X}$ and $z_{i m}^{Y}$ are concerned with the horizontal and vertical facility assignment respectively (e.g. in Fig. 1.b, $z_{53}^{X}=z_{52}^{Y}=1$ represents that M5 is assigned to column 3 and row 2).

The MIP formulation of the grid representation quadratic assignment problem (GRQAP) is as follows:

GRQAP: $\operatorname{Min} \sum_{i} \sum_{k>i} c_{i k} \cdot f_{i k}\left(d x_{i k}^{+}+d x_{i k}^{-}+d y_{i k}^{+}+d y_{i k}^{-}\right)$

subject to: 
$d x_{i k}^{+}-d x_{i k}^{-}=\sum_{m}\left(z_{i m}^{X}-z_{k m}^{X}\right) a_{m}, \quad \forall i<k$,

$d y_{i k}^{+}-d y_{i k}^{-}=\sum_{n}^{m}\left(z_{i n}^{Y}-z_{k n}^{Y}\right) b_{n}, \quad \forall i<k$,

$\sum z_{i m}^{X}=1, \quad \forall i$

$\sum^{m} z_{i n}^{Y}=1, \quad \forall i$

$\sum_{i}^{n} \gamma_{i m n} \leq 1, \quad \forall m, n$,

$\gamma_{i m n} \geq z_{i m}^{X}+z_{i n}^{Y}-1, \quad \forall i, m, n$,

$\gamma_{\text {imn }} \geq 0, \quad \forall i, m, n$,

$d x_{i k}^{+}, d x_{i k}^{-}, d y_{i k}^{+}, d y_{i k}^{-}, \quad \forall i<k$,

$z_{i m}^{X} \in\{0,1\}, \quad \forall i, m$,

$z_{\text {in }}^{Y} \in\{0,1\}, \quad \forall i, n$,

where $a_{m}$ denotes horizontal coordinate of center of column $m$ and $b_{n}$ denotes vertical coordinate of center of row $n$ with respect to the origin. Objective function (8) minimizes the total material handling cost. Constraints (9) and (10) linearize the absolute value term in the horizontal and vertical distance function, constraints (11) and (12) ensure that each facility is assigned to only one column and row, respectively. Constraint (13) restricts that each candidate point is occupied by utmost one facility. Constraints (14) linearizes the nonlinearity due to the multiplication of two binary variables (where $\left.\gamma_{i m n}=z_{i m}^{X} . z_{i n}^{Y}\right)$. Finally constraints (15)-(18) are the logical binary and non-negativity requirements on the decision variables.

Table 1shows the maximum number of binary and positive variables as well as maximum number of constraints, for both models. Note that in the model of QAP, $|m| .|n|$ is replaced instead of $|j|$ (since $|m| \cdot|n|=|j|)$.



a) Numbered candidate points



b) Numbered rows and columns

Fig. 1. Two different approaches for assigning facilities to the candidate points

Table 1

Characteristics of the QAP, GRQAP

\begin{tabular}{cll}
\hline QAP & No. Binary variables & $|i| .|j|=|i| .|m| .|n|$ \\
& No. Positive variables & $|i| .|j|=|i| .|m| .|n|$ \\
& No. Constraints & $|i| .|j|+|i|+|j|=|i| .|m| .|n|+|i|+|m| .|n|$ \\
\hline GRQAP & No. Binary variables & $|i|(|m|+|n|)$ \\
& No. Positive variables & $|i|(2(|i|-1)+|m| .|n|)$ \\
& No. Constraints & $(|i|+1)(|m| .|n|+|i|)$ \\
\hline
\end{tabular}

$|i|$ : Number of facilities, $|j|=|m| .|n|$ : Number of candidate points, $|m|$ : Number of columns, $|n|:$ Number of rows 


\section{Numerical example 1}

In this section, several small and small-to-medium scale problems have been selected from the literature in order to compare the GRQAP and QAP. In these examples it is assumed that the dimension of all facilities is $1 \times 1$. All problem instances were solved by using CPLEX 10 on a PC with $2.4 \mathrm{GHz}$ CPU, 2 GB memory, and Windows 7 operating system. The computational results have been reported in Table 2.

Table 2

Computational results of small and small-to-medium scale problems to compare QAP and GRQAP

\begin{tabular}{|c|c|c|c|c|c|c|c|c|c|c|c|c|c|c|}
\hline \multirow{2}{*}{$\begin{array}{c}\text { Proble } \\
\mathrm{m} \\
\text { name }\end{array}$} & \multirow[t]{2}{*}{ Source } & \multirow{2}{*}{$\frac{\text { Size }}{i \times m \times n}$} & \multicolumn{6}{|c|}{ QAP } & \multicolumn{6}{|c|}{ GRQAP } \\
\hline & & & $\begin{array}{c}\text { No. } \\
\text { binary } \\
\text { variable } \\
\text { s }\end{array}$ & $\begin{array}{c}\text { No. } \\
\text { positive } \\
\text { variable } \\
\mathrm{s}\end{array}$ & $\begin{array}{c}\text { No. } \\
\text { constraint } \\
\text { s }\end{array}$ & $\begin{array}{c}\text { CPU } \\
\text { time (s) }\end{array}$ & Obj. & $\begin{array}{c}\text { Opt. } \\
\text { Gap\% }\end{array}$ & $\begin{array}{c}\text { No. } \\
\text { binary } \\
\text { variable } \\
\text { s }\end{array}$ & $\begin{array}{c}\text { No. } \\
\text { positive } \\
\text { variable } \\
\mathrm{s}\end{array}$ & $\begin{array}{c}\text { No. } \\
\text { constraint } \\
\text { s }\end{array}$ & $\begin{array}{c}\text { CPU } \\
\text { time (s) }\end{array}$ & Obj. & $\begin{array}{c}\text { Opt. } \\
\text { Gap } \\
\%\end{array}$ \\
\hline \multirow[t]{2}{*}{ HK4 } & Heragu \& & $4 \times 4 \times 1$ & 16 & 16 & 24 & 0.180 & 40 & $0 \%$ & 20 & 40 & 40 & 0.055 & 40 & $0 \%$ \\
\hline & Kusiak(1991) & $4 \times 2 \times 2$ & 16 & 16 & 24 & 0.096 & 34 & $0 \%$ & 16 & 40 & 40 & 0.060 & 34 & $0 \%$ \\
\hline \multirow[t]{2}{*}{ LW5 } & Love \& & $5 \times 5 \times 1$ & 25 & 25 & 35 & 0.174 & 30 & $0 \%$ & 30 & 65 & 60 & 0.059 & 30 & $0 \%$ \\
\hline & Wong(1976) & $5 \times 3 \times 2$ & 30 & 30 & 41 & 0.181 & 28 & $0 \%$ & 25 & 70 & 66 & 0.168 & 28 & $0 \%$ \\
\hline \multirow[t]{3}{*}{$\mathrm{S} 8 \mathrm{H}$} & Simmons(1969) & $8 \times 8 \times 1$ & 64 & 64 & 80 & 3.367 & 200 & $0 \%$ & 72 & 176 & 144 & 1.014 & 200 & $0 \%$ \\
\hline & & $8 \times 4 \times 2$ & 64 & 64 & 80 & 5.523 & 143 & $0 \%$ & 48 & 176 & 144 & 3.096 & 143 & $0 \%$ \\
\hline & & $8 \times 3 \times 3$ & 72 & 72 & 89 & 18.384 & 138 & $0 \%$ & 48 & 184 & 153 & 11.965 & 138 & $0 \%$ \\
\hline \multirow[t]{3}{*}{$\mathrm{S} 8 \mathrm{H}$} & Simmons(1969) & $8 \times 8 \times 1$ & 64 & 64 & 80 & 11.561 & 488 & $0 \%$ & 72 & 176 & 144 & 5.531 & 488 & $0 \%$ \\
\hline & & $8 \times 4 \times 2$ & 64 & 64 & 80 & 15.183 & 325 & $0 \%$ & 48 & 176 & 144 & 7.835 & 325 & $0 \%$ \\
\hline & & $8 \times 3 \times 3$ & 72 & 72 & 89 & 38.504 & 313 & $0 \%$ & 48 & 184 & 153 & 21.877 & 313 & $0 \%$ \\
\hline \multirow[t]{3}{*}{ S9 } & Simmons(1969) & $9 \times 9 \times 1$ & 81 & 81 & 99 & 108.180 & 734 & $0 \%$ & 90 & 225 & 180 & 29.485 & 734 & $0 \%$ \\
\hline & & $9 \times 5 \times 2$ & 90 & 90 & 109 & 404.782 & 490 & $0 \%$ & 63 & 234 & 190 & 224.252 & 490 & $0 \%$ \\
\hline & & $9 \times 3 \times 3$ & 81 & 81 & 99 & 138.551 & 441 & $0 \%$ & 54 & 225 & 180 & 80.783 & 441 & $0 \%$ \\
\hline \multirow{2}{*}{$\mathrm{S} 9 \mathrm{H}$} & & $9 \times 5 \times 2$ & 90 & 90 & 109 & 194.995 & 294 & $0 \%$ & 63 & 234 & 190 & 69.594 & 294 & $0 \%$ \\
\hline & & $9 \times 3 \times 3$ & 81 & 81 & 99 & 90.176 & 274 & $0 \%$ & 54 & 225 & 180 & 38.335 & 274 & $0 \%$ \\
\hline \multirow[t]{3}{*}{ A9 } & Adel El-Baz & $9 \times 9 \times 1$ & 81 & 81 & 99 & 6.018 & 65239 & $0 \%$ & 90 & 225 & 180 & 1.634 & 65239 & $0 \%$ \\
\hline & (2004) & $9 \times 5 \times 2$ & 90 & 90 & 109 & 9.874 & 4854 & $0 \%$ & 63 & 234 & 190 & 9.959 & 4854 & $0 \%$ \\
\hline & & $9 \times 3 \times 3$ & 81 & 81 & 99 & 11.064 & 4818 & $0 \%$ & 54 & 225 & 180 & 9.783 & 4818 & $0 \%$ \\
\hline \multirow[t]{3}{*}{$\mathrm{S} 10$} & Simmons (1969) & $10 \times 10 \times 1$ & 100 & 100 & 120 & 373.243 & 492 & $0 \%$ & 110 & 280 & 220 & 16.644 & 492 & $0 \%$ \\
\hline & & $10 \times 5 \times 2$ & 100 & 100 & 120 & 585.348 & 334 & $0 \%$ & 70 & 280 & 220 & 193.374 & 334 & $0 \%$ \\
\hline & & $10 \times 4 \times 3$ & 120 & 120 & 142 & 1614.011 & 315 & $0 \%$ & 70 & 300 & 242 & 970.784 & 315 & $0 \%$ \\
\hline \multirow[t]{3}{*}{$\overline{L W 11}$} & Love \& Wong & $11 \times 11 \times 1$ & 121 & 121 & 143 & 4063.60 & 1207 & $0 \%$ & 132 & 341 & 264 & 74.876 & 1207 & $0 \%$ \\
\hline & $(1976)$ & $11 \times 6 \times 2$ & 132 & 132 & 155 & 2744.66 & 795 & $26.36 \%$ & 88 & 352 & 276 & 3631.27 & 793 & $0 \%$ \\
\hline & & $11 \times 4 \times 3$ & 132 & 132 & 155 & 4662.41 & 725 & $0 \%$ & 77 & 352 & 276 & 5256.94 & 725 & $0 \%$ \\
\hline \multirow[t]{3}{*}{$\mathrm{S} 11$} & Simmons (1969) & $11 \times 11 \times 1$ & 121 & 121 & 143 & 3509.11 & 1207 & $29.68 \%$ & 132 & 341 & 264 & 105.261 & 1207 & $0 \%$ \\
\hline & & $11 \times 6 \times 2$ & 132 & 132 & 155 & 2889.62 & 793 & $26.84 \%$ & 88 & 352 & 276 & 1485.52 & 793 & $0 \%$ \\
\hline & & $11 \times 4 \times 3$ & 132 & 132 & 155 & 2922.51 & 725 & $29.27 \%$ & 77 & 352 & 276 & 7220.92 & 725 & $0 \%$ \\
\hline \multirow[t]{2}{*}{ A12 } & Adel El-Baz & $12 \times 12 \times 1$ & 144 & 144 & 168 & 1893.83 & 11055 & $0 \%$ & 156 & 408 & 312 & 40.661 & 11055 & $0 \%$ \\
\hline & & $12 \times 6 \times 2$ & 144 & 144 & 168 & 1877.24 & 8460 & $41.98 \%$ & 96 & 408 & 312 & 517.237 & 8460 & $0 \%$ \\
\hline
\end{tabular}

i: number of facilities, m: number of rows, $n$ : number of columns

$*$ in this case solver was interrupted due to insufficient physical memory

All numerical instances were solved optimally by the GRQAP; while the QAP could not solve some cases optimally and the solver was interrupted due to insufficient physical memory. It means that the GRQAP needs relatively less physical memory. In addition, the results show that the GRQAP can solve the problem in shorter computational time than QAP. The average improvement percent in solution time(except the cases which weren't solved optimally) is $52.52 \%$. So it is concluded that the GRQAP can solve small and small-to-medium scale problems about two times as fast as the QAP.

\section{Formulating the integrated facility layout problem}

In this section, the integrated facility layout problem (IFLP) is formulated, under the following notations:

Indices:

$i, j \quad$ Index of departments

$k, l \quad$ Index of facilities 
$m \quad$ Index of columns

$n \quad$ Index of rows

Model parameters:

C number of departments

$w_{i} \quad$ width of department $i$

$h_{i} \quad$ height of departmenti

$M_{i} \quad$ number of facilities of departmenti

$R o_{i} \quad$ number of rows of department $i$

$\mathrm{Co}_{i} \quad$ number of columns of department $i$

$a_{i m} \quad$ length of center of $m^{\text {th }}$ column of cell $i$ in x-axis with respect to the left edge of cell $i$

$b_{i n} \quad$ length of center of $n^{\text {th }}$ row of cell $i$ in y-axis with respect to the down edge of cell $i$

$L h_{i j} \quad$ least horizontal distance between departmenti and department $j$

$L v_{i j} \quad$ least vertical distance between department $i$ and department $j$

$f_{i j k l} \quad$ amount of material flow between facility $k$ of department $i$ and facility $l$ of department $j$

$c_{i j k l} \quad$ material handling cost per unit flow per unit distance traveled between facility $k$ of department $i$ and facilityl of department $j$

$B M \quad$ a large number

\section{Decision variables:}

$\left(x_{i}, y_{i}\right) \quad$ coordinates of center of department $i$

$u_{i}$

$z_{i k m}^{X}$

$z_{i k n}^{Y}$

$d x_{i j k l}^{+}+d x_{i j k l}^{-}$

$d y_{i j k l}^{+}+d y_{i j k l}^{-} \quad$ vertical distance between facility $k$ of departmenti and facility $l$ of department $j$

\section{The mathematical model:}

As it was concluded in the previous section, in contrast with the traditional QAP, the GRQAP can solve problems in a shorter computational time and with less physical memory. After combining GRQAP and continuous layout model and applying some standard linearization methods, the IFLP is formulated as the following MIP model:

IFLP:

$$
\begin{aligned}
\min \sum_{i=1}^{C-1} \sum_{j=i+1}^{C} \sum_{k=1}^{M_{i}} & \sum_{l=1}^{M_{j}} f_{i j k l} \cdot c_{i j k l}\left(d x_{i j k l}^{+}+d x_{i j k l}^{-}+d y_{i j k l}^{+}+d y_{i j k l}^{-}\right) \\
& +\sum_{i=1}^{C} \sum_{k=1}^{M_{i}-1} \sum_{l=k+1}^{M_{j}} f_{i k l} \cdot c_{i k l}\left(d x_{i k l}^{+}+d x_{i k l}^{-}+d y_{i k l}^{+}+d y_{i k l}^{-}\right)
\end{aligned}
$$

subject to: 
$\sum_{m=1}^{c o_{i}}\left(z_{i k m}^{X}-z_{i l m}^{X}\right) a_{i m}=d x_{i k l}^{+}-d x_{i k l}^{-}, \quad i=1, \ldots, C, \quad k=1, \ldots, M_{i}-1, \quad l=k+1, \ldots, M_{i}$

$\sum_{n=1}^{R o_{i}}\left(z_{i k n}^{Y}-z_{i l n}^{Y}\right) b_{i n}=d y_{i k l}^{+}-d y_{i k l}^{-}, \quad i=1, \ldots, C, \quad k=1, \ldots, M_{i}-1, \quad l=k+1, \ldots, M_{i}$

$x_{i}-x_{j}-\left(1-u_{i}\right) \frac{w_{i}}{2}+\left(1-u_{j}\right) \frac{w_{j}}{2}-u_{i} \frac{h_{i}}{2}+u_{j} \frac{h_{j}}{2}+\sum_{m=1}^{c o_{i}} z_{i k m}^{X} \cdot a_{i m}-\sum_{m=1}^{c o_{j}} z_{j l m}^{X} a_{j m}+\xi_{i k}-\xi_{j l}=d x_{i j k l}^{+}-d x_{i j k l}^{-}$, $i=1, \ldots, C-1, \quad j=i+1, \ldots, C, \quad k=1, \ldots, M_{i}, \quad l=1, \ldots, M_{j}$

$y_{i}-y_{j}-u_{i} \frac{w_{i}}{2}+u_{j} \frac{w_{j}}{2}-\left(1-u_{i}\right) \frac{h_{i}}{2}+\left(1-u_{j}\right) \frac{h_{j}}{2}+\sum_{n=1}^{R o_{i}} z_{i k n}^{Y} \cdot b_{i n}-\sum_{n=1}^{R o_{j}} z_{j l n}^{Y} \cdot b_{j n}-\xi_{i k}+\xi_{j l}=d y_{i j k l}^{+}-d y_{i j k l}^{-}$, $i=1, \ldots, C-1, \quad j=i+1, \ldots, C, \quad k=1, \ldots, M_{i}, \quad l=1, \ldots, M_{j}$

$\sum_{n=1}^{R o_{i}} z_{i k n}^{Y} \cdot b_{i n}-\sum_{m=1}^{C o_{i}} z_{i k m}^{X} \cdot a_{i m}-\left(1-u_{i}\right) B M \leq \xi_{i k} \leq \sum_{n=1}^{R o_{i}} z_{i k n}^{Y} \cdot b_{i n}-\sum_{m=1}^{C o_{i}} z_{i k m}^{X} \cdot a_{i m}+\left(1-u_{i}\right) B M, \quad i=1, \ldots, C$,

$-u_{i} . B M \leq \xi_{i k} \leq u_{i} . B M, \quad i=1, \ldots, C, \quad k=1, \ldots, M_{i}$

$\sum_{m=1}^{C o_{i}} z_{i k m}^{X}=1, \quad i=1, \ldots, C, \quad k=1, \ldots, M_{i}$

$\sum_{n=1}^{R o_{i}} z_{i k n}^{Y}=1, \quad i=1, \ldots, C, \quad k=1, \ldots, M_{i}$

$\sum_{k=1}^{M_{i}} \gamma_{i k m n} \leq 1, \quad i=1, \ldots, C, \quad m=1, \ldots, C o_{i}, \quad n=1, \ldots, R o_{i}$

$\gamma_{i k m n} \geq z_{i k m}^{X}+z_{i k n}^{Y}-1, \quad i=1, \ldots, C, \quad k=1, \ldots, M_{i}, \quad m=1, \ldots, C o_{i}, \quad n=1, \ldots, R o_{i}$

$x_{j}-x_{i}+B M \cdot p_{i j}+B M \cdot v_{i j} \geq \frac{1}{2}\left[\left(1-u_{i}\right) w_{i}+u_{i} \cdot h_{i}+\left(1-u_{j}\right) w_{j}+u_{j} \cdot h_{j}\right]+L h_{i j}, \quad i=1, \ldots, C-1$, $j=i+1, \ldots, C$

$x_{i}-x_{j}+B M\left(1-p_{i j}\right)+B M \cdot v_{i j} \geq \frac{1}{2}\left[\left(1-u_{i}\right) w_{i}+u_{i} \cdot h_{i}+\left(1-u_{j}\right) w_{j}+u_{j} \cdot h_{j}\right]+L h_{i j}, \quad i=1, \ldots, C-1$, $j=i+1, \ldots, C$

$y_{i}-y_{j}+B M . q_{i j}+B M\left(1-v_{i j}\right) \geq \frac{1}{2}\left[u_{i} \cdot w_{i}+\left(1-u_{i}\right) h_{i}+u_{j} \cdot w_{j}+\left(1-u_{j}\right) h_{j}\right]+L v_{i j}, \quad i=1, \ldots, C-1$, $j=i+1, \ldots, C$

$y_{i}-y_{j}+B M\left(1-q_{i j}\right)+B M\left(1-v_{i j}\right) \geq \frac{1}{2}\left[u_{i} \cdot w_{i}+\left(1-u_{i}\right) h_{i}+u_{j} \cdot w_{j}+\left(1-u_{j}\right) h_{j}\right]+L v_{i j}$,

$i=1, \ldots, C-1, \quad j=i+1, \ldots, C$

$d x_{i j k l}^{+}, d x_{i j k l}^{-}, d y_{i j k l}^{+}, d y_{i j k l}^{-} \geq 0, \quad i=1, \ldots, C, \quad j=i+1, \ldots, C, \quad k=1, \ldots, M_{i}, \quad l=1, \ldots, M_{j}$

$\xi_{i k}=$ free $, \quad i=1, \ldots, C, \quad k=1, \ldots, M_{i}$

$p_{i j}, q_{i j} \in\{0,1\}, \quad i=1, \ldots, C-1, \quad j=i+1, \ldots, C$

$x_{i}, y_{i} \geq 0, \quad i=1, \ldots, C$

$u_{i} \in\{0,1\}, \quad i=1, \ldots, C$

$z_{i k m}^{X} \in\{0,1\}, \quad i=1, \ldots, C, \quad k=1, \ldots, M_{i}, \quad m=1, \ldots, C o_{i}$

$z_{i k n}^{Y} \in\{0,1\}, \quad i=1, \ldots, C, \quad k=1, \ldots, M_{i}, \quad n=1, \ldots, R o_{i}$

$\gamma_{i k m n} \geq 0, \quad i=1, \ldots, C, \quad k=1, \ldots, M_{i}, \quad m=1, \ldots, C o_{i}, \quad n=1, \ldots, R o_{i}$ 
The objective function (19) minimizes the total material handling cost, including inter and intradepartment material handling costs. Note that in the intra-department material handling cost function, the indexes of $i i k l$ have been reduced to $i k l$, (e.g. $f_{i i k l}=f_{i k l}$ or $d x_{i i k l}^{+}=d x_{i k l}^{+}$). Constraints (20) and (21) linearize the absolute value term in the intra-department rectilinear distance function, constraints (22) and (23) linearize the absolute value term in the inter-department rectilinear distance function, constraints (24) and (25) linearize the quadratic term due to the product of a binary variable and a free expression within the absolute value terms in constraints (22) and (23) i.e. $\xi_{i k}=u_{i}\left(\sum_{n=1}^{R o_{i}} z_{i k n}^{Y} . b_{i n}-\right.$ $\left.\sum_{m=1}^{C o_{i}} z_{i k m}^{X} . a_{i m}\right)$, where $\xi_{i k}$ is a free auxiliary variable. This quadratic term has been linearized by applying the following proposition.

Proposition 1. Set of constraints (24) and (25) linearize the following quadratic term: $u_{i}\left(\sum_{n=1}^{R o_{i}} z_{i k n}^{Y} \cdot b_{i n}-\sum_{m=1}^{C o_{i}} z_{i k m}^{X} \cdot a_{i m}\right)$.

Proof. This can be shown for each of two possible cases:

Case 1: $u_{i}=1$. In this case constraints (24) and (25) are reduced to the following constraints:

$\sum_{n=1}^{R o_{i}} z_{i k n}^{Y} \cdot b_{i n}-\sum_{m=1}^{C o_{i}} z_{i k m}^{X} \cdot a_{i m} \leq \xi_{i k} \leq \sum_{n=1}^{R o_{i}} z_{i k n}^{Y} \cdot b_{i n}-\sum_{m=1}^{C o_{i}} z_{i k m}^{X} \cdot a_{i m}, \quad i=1, \ldots, C, \quad k=1, \ldots, M_{i}$

$-B M \leq \xi_{i k} \leq B M, \quad i=1, \ldots, C, \quad k=1, \ldots, M_{i}$

Therefore it is concluded that $\xi_{i k}$ is equal to $\sum_{n=1}^{R o_{i}} z_{i k n}^{Y} . b_{i n}-\sum_{m=1}^{C o_{i}} z_{i k m}^{X} . a_{i m}$.

Case 2: $u_{i}=0$. In this case constraints (24) and (25) are reduced to the following constraints:

$-B M \leq \xi_{i k} \leq B M, \quad i=1, \ldots, C, \quad k=1, \ldots, M_{i}$

$0 \leq \xi_{i k} \leq 0, \quad i=1, \ldots, C, \quad k=1, \ldots, M_{i}$

Thus it is concluded that $\xi_{i k}=0$.

Also, Table 3 illustrates how the linearization in Proposition 1 works through four numerical examples.

Table 3

Examples to the linearization stated in proposition 1

\begin{tabular}{|c|c|c|c|c|}
\hline & Example 1 & Example 2 & Example 3 & Example 4 \\
\hline$R o_{i}$ & 9 & 4 & 9 & 4 \\
\hline$\sum_{n=1} z_{i k n}^{Y} \cdot b_{i n}$ & & & & \\
\hline $\mathrm{Co}_{i}$ & 6 & 6 & 6 & 6 \\
\hline$R o_{i}$ & 3 & -2 & 3 & -2 \\
\hline$u_{i}$ & 1 & 1 & 0 & 0 \\
\hline Imposed constraints & $\begin{array}{l}3 \leq \xi_{i k} \leq 3 \\
-B M \leq \xi_{i k} \leq B M\end{array}$ & $\begin{array}{l}-2 \leq \xi_{i k} \leq-2 \\
-B M \leq \xi_{i k} \leq B M\end{array}$ & $\begin{array}{l}-B M \leq \xi_{i k} \leq B M \\
0 \leq \xi_{i k} \leq 0\end{array}$ & $\begin{array}{l}-B M \leq \xi_{i k} \leq B M \\
0 \leq \xi_{i k} \leq 0\end{array}$ \\
\hline $\operatorname{Result}\left(\xi_{i k}\right)$ & 3 & -2 & $\mathbf{0}$ & $\mathbf{0}$ \\
\hline
\end{tabular}

The functions of remaining constraints are as follows: Constraints (26) and (27) ensure that each facility is assigned to one column and one row respectively, constraints (28) restricts that each 
candidate point in each department can be occupied by utmost one facility, constraint (29) linearizes the nonlinearity of $z_{i k m}^{X} \cdot z_{i k n}^{Y}$, where the auxiliary variable $\gamma_{i k m n}$ is equal to $z_{i k m}^{X} \cdot z_{i k n}^{Y}$. Set of constraints (30)-(33) ensure that departments do not overlap, also in these constraints, $p_{i j}, q_{i j}$ and $v_{i j}$ are auxiliary binary variables. Finally, constraints (34)-(41) are the logical binary and non-negativity requirements on the decision variables.

\section{Numerical example 2}

As it was mentioned before, one of the applications of the proposed model is in the layout design of CMS i.e. after specifying machine cells and part families. To show this application, several small, medium and large scale numerical examples have been selected from the literature of CMS, and the IFLP is applied on them. Note that in these examples expression of 'cell' is equivalent to 'department' and term of 'machine' is equivalent to 'facility'.

\subsection{Small scale problems}

The first small scale problem (S1) has been selected from Akturk \& Turkcan (2000); they concluded that 3 machine cells must be formed to produce 20 parts. The information corresponds to machine cells and material flow cost $\left(f_{i j k l} . c_{i j k l}\right)$ among machines has been given in Table 4 . It is necessary to mention that this table has been obtained according to demand of parts, processing routes of parts and inter and intra-cell material handling cost, that are exist in the reference paper.

\section{Table 4}

The material flowcost among machines (problem S1)

\begin{tabular}{|c|c|c|c|c|c|c|c|c|c|c|c|c|c|}
\hline & $1-1$ & $1-2$ & $1-3$ & $1-4$ & $1-5$ & $1-6$ & $2-1$ & $2-2$ & $2-3$ & $3-1$ & $3-2$ & $3-3$ & $3-4$ \\
\hline $1-1$ & 0.0 & 1104.8 & 0 & 0 & 0 & 391.3 & 0 & 0 & 0 & 0 & 0 & 0 & 0 \\
\hline $1-2$ & & 0 & 1952.1 & 1192.9 & 0 & 924.8 & 0 & 0 & 0 & 0 & 0 & 0 & 0 \\
\hline $1-3$ & & & 0 & 0 & 0 & 0 & 0 & 0 & 0 & 287.6 & 0 & 0 & 0 \\
\hline $1-4$ & & & & 0 & 0 & 0 & 0 & 0 & 0 & 0 & 0 & 0 & 0 \\
\hline $1-5$ & & & & & 0 & 2104.3 & 0 & 0 & 0 & 0 & 0 & 672.0 & 0 \\
\hline $1-6$ & & & & & & 0 & 0 & 0 & 0 & 0 & 0 & 0 & 0 \\
\hline $2-1$ & & & & & & & 0 & 1548.8 & 0 & 0 & 0 & 368.7 & 0 \\
\hline $2-2$ & & & & & & & & 0 & 2138.5 & 0 & 0 & 0 & 0 \\
\hline $2-3$ & & & & & & & & & 0 & 0 & 0 & 0 & 0 \\
\hline $3-1$ & & & & & & & & & & 0 & 2481.1 & 537.6 & 0 \\
\hline $3-2$ & & & & & & & & & & & 0 & 2019.4 & 2229.0 \\
\hline $3-3$ & & & & & & & & & & & & 0 & 1367.2 \\
\hline $3-4$ & & & & & & & & & & & & & 0 \\
\hline
\end{tabular}

The problem S1 has been solved for different cell sizes as the following cases: S1-1, S1-2 and S1-3. Table 5 shows the dimension of each case.

Table 5

Dimension of the cells in each case of S1

\begin{tabular}{|c|c|c|c|c|c|c|c|c|c|c|c|c|}
\hline \multirow[t]{2}{*}{ Cell } & \multicolumn{4}{|l|}{ S1-1 } & \multicolumn{4}{|l|}{ S1-2 } & \multicolumn{4}{|l|}{ S1-3 } \\
\hline & Width & Height & No. rows & No. columns & Width & Height & No. rows & No. columns & Width & Height & No. rows & No. columns \\
\hline 1 & 6 & 1 & 1 & 6 & 3 & 2 & 2 & 3 & 3 & 2 & 2 & 3 \\
\hline 2 & 3 & 1 & 1 & 3 & 3 & 1 & 1 & 3 & 3 & 1 & 1 & 3 \\
\hline 3 & 4 & 1 & 1 & 4 & 4 & 1 & 1 & 4 & 2 & 2 & 2 & 2 \\
\hline
\end{tabular}

Table 7 summarizes optimum layout of each problem, including cell layout and layout of machines within the cells. The results revealed that by changing the number of rows and columns in each cell, the total material handling cost has been changed, considerably. For example, in S1-1, the layout of machines within all cells are single row and the resulted material handling cost is 26779.6, while in S12 by changing the number of rows and columns the material handling cost has been reduced to 24444.3 
with a gap of $9 \%$; or by comparing S1-1 and S1-2, it is concluded that the material handling cost has been reduced about 5\%. Therefore, in order to attain better solution, the decision maker should consider different dimension of the cells. The next small scale problem (S2) is selected from Cheng et al. (1966); this problem contains 20 parts and 10 machines. They grouped parts into 3 part families that should be produced using 3 machine cells with 5, 3 and 4 machines in cell 1, 2 and 3 respectively. Table 6 presents the material flow among machines, for the proposed problem. In addition, the unit intra and inter-cell handling cost per unit distance is assumed 5 and 7 units, respectively. This problem has been solved in three cases, including S2-1, S2-2 and S2-3. In S2-1 the layout of machines within all cells is linear and in S2-2it is multi rows for cell 1 and 3. Also S2-3 is similar to S2-2, 0.5 units for aisle distance.

\section{Table 6}

Material flow among machines (Problem S2)

\begin{tabular}{|c|c|c|c|c|c|c|c|c|c|c|c|c|}
\hline & $1-1$ & $1-2$ & $1-3$ & $1-4$ & $1-5$ & $2-1$ & $2-2$ & $2-3$ & $3-1$ & $3-2$ & $3-3$ & $3-4$ \\
\hline $1-1$ & 0 & 148 & 0 & 0 & 0 & 310 & 0 & 0 & 94 & 0 & 0 & 32 \\
\hline $1-2$ & & 0 & 246 & 36 & 122 & 44 & 0 & 0 & 0 & 140 & 0 & 24 \\
\hline $1-3$ & & & 0 & 102 & 122 & 0 & 0 & 0 & 0 & 0 & 0 & 68 \\
\hline $1-4$ & & & & 0 & 128 & 0 & 0 & 24 & 0 & 0 & 0 & 36 \\
\hline $1-5$ & & & & & 0 & 0 & 0 & 82 & 0 & 0 & 0 & 142 \\
\hline $2-1$ & & & & & & 0 & 130 & 0 & 18 & 216 & 0 & 0 \\
\hline $2-2$ & & & & & & & 0 & 52 & 0 & 18 & 0 & 96 \\
\hline $2-3$ & & & & & & & & 0 & 0 & 0 & 0 & 662 \\
\hline $3-1$ & & & & & & & & & 0 & 96 & 0 & 0 \\
\hline $3-2$ & & & & & & & & & & 0 & 234 & 22 \\
\hline 3-3 & & & & & & & & & & & 0 & 342 \\
\hline $3-4$ & & & & & & & & & & & & 0 \\
\hline
\end{tabular}

S2-1, S2-2 and S2-3 were solved optimally and the results have been summarized in Table 7. The results show that, unlike $\mathrm{S} 1$, by increasing the number of rows, total material handling cost has been increased.

\section{Table 7}

The computational results of small scale problems

\begin{tabular}{|c|c|c|c|c|c|c|c|}
\hline Problem & Source & Size & Intra-cell layout & Coordinates of the cells & Cells orientation & Objective value & CPU time (s) \\
\hline S1-1 & $\begin{array}{c}\text { Akturk \& Turkcan } \\
(2000)\end{array}$ & $3 \times 13$ &  & $\begin{array}{l}\text { Cell 1: }(0,2.5) \\
\text { Cell 2: }(3,0) \\
\text { Cell 3: }(1,0.5)\end{array}$ & $\begin{array}{l}\text { Cell 1: vertical } \\
\text { Cell 2: horizontal } \\
\text { Cell 3: vertical }\end{array}$ & 26779.6 & 2.140 \\
\hline S1-2 & $\begin{array}{l}\text { Akturk \& Turkcan } \\
(2000)\end{array}$ & $3 \times 13$ & $\begin{array}{l}\text { Cell 1: } \\
\begin{array}{rllll}1-5 & 1-6 & 1-1 & \\
1-3 & 1-2 & 1-4 & \\
\text { Cell 2: } & 2-3 & 2-2 & 2-1 & \\
\text { Cell 3: } & 3-1 & 3-2 & 3-3 & 3-4\end{array}\end{array}$ & $\begin{array}{l}\text { Cell 1: }(4,0) \\
\text { Cell 2: }(0,0.5) \\
\text { Cell 3: }(2,0)\end{array}$ & $\begin{array}{l}\text { Cell 1: horizontal } \\
\text { Cell 2: horizontal } \\
\text { Cell 3: vertical }\end{array}$ & 25479.1 & 11.830 \\
\hline S1-3 & $\begin{array}{c}\text { Akturk \& Turkcan } \\
(2000)\end{array}$ & $3 \times 13$ & $\begin{array}{rrrr}\text { Cell 1: } & 1-5 & 1-6 & 1-1 \\
& 1-3 & 1-2 & 1-4 \\
\text { Cell 2: } & 2-1 & 2-2 & 2-3 \\
\text { Cell 3: } & 3-4 & 3-3 & \\
& 3-2 & 3-1 & \\
\end{array}$ & $\begin{array}{l}\text { Cell 1: }(2.5,0) \\
\text { Cell 2: }(0.5,2.5) \\
\text { Cell 3: }(0,0)\end{array}$ & $\begin{array}{l}\text { Cell 1: horizontal } \\
\text { Cell 2: vertical } \\
\text { Cell 3: horizontal }\end{array}$ & 24444.3 & 14.743 \\
\hline S2-1 & Cheng et al. (1966) & $3 \times 12$ & $\begin{array}{llllll}\text { Cell 1: } & 1-4 & 1-5 & 1-3 & 1-2 & 1-1 \\
\text { Cell 2: } & 2-3 & 2-2 & 2-1 & & \\
\text { Cell 3: } & 3-4 & 3-3 & 3-2 & 3-1 & \end{array}$ & $\begin{array}{l}\text { Cell 1: }(0,0) \\
\text { Cell 2: }(2,0) \\
\text { Cell 3: }(1,0.5)\end{array}$ & $\begin{array}{l}\text { Cell 1: vertical } \\
\text { Cell 2: vertical } \\
\text { Cell 3: vertical }\end{array}$ & 32750 & 6.796 \\
\hline S2-2 & Cheng et al. (1966) & $3 \times 12$ & 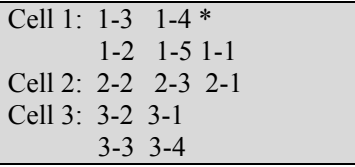 & $\begin{array}{l}\text { Cell 1: }(0.5,2.5) \\
\text { Cell 2: }(1.5,0) \\
\text { Cell 3: }(0,0.5)\end{array}$ & $\begin{array}{l}\text { Cell 1: horizontal } \\
\text { Cell 2: vertical } \\
\text { Cell 3: horizontal }\end{array}$ & 34430 & 29.322 \\
\hline S2-3 & Cheng et al.(1966) & $3 \times 12$ & $\begin{array}{llll}\text { Cell 1: } & 1-4 & 1-3 & * \\
& 1-5 & 1-2 & 1-1 \\
\text { Cell 2: } & 2-2 & 2-3 & 2-1 \\
\text { Cell 3: } & 3-4 & 3-2 & \\
& 3-3 & 3-1 & \end{array}$ & $\begin{array}{l}\text { Cell 1: }(3,1) \\
\text { Cell 2: }(0,2) \\
\text { Cell 3: }(0.5,0)\end{array}$ & $\begin{array}{l}\text { Cell 1: vertical } \\
\text { Cell 2: horizontal } \\
\text { Cell 3: horizontal }\end{array}$ & 42583 & 17.218 \\
\hline
\end{tabular}

* Empty candidate point 


\subsection{Medium scale problems}

In this section in order to evaluate the performance of IFLP on medium scale problems, several numerical examples are selected from Adil \& Rajamani (2000), Harhalakis et al.(1990) and Ramabhatta \& Nagi (1996).

The first medium scale problem has been selected from Adil and Rajamani (2000). They implemented a simulated annealing algorithm (SAA) on a CMS problem from Harhalakis et al. (1990) with 20 parts and 20 machines, to minimize the number of inter-cell moves. They concluded that the solution obtained by the SAA is better than the solution reported by Harhalakis et al. (1990). They specified 3 machine cells with 13 inter-cell moves, while Harhalakis et al. (1990) specified 4 machine cells with 14 inter-cell moves. Table 8 and Table 9 show the material flow among machines based on the solutions reported by Adil \& Rajamani (2000) and Harhalakis et al. (1990), respectively. In these problems the material flow are calculated according to processing routes of parts. In addition, it is assumed that the unit inter and intra-cell material handling cost per unit distance are 15 and 10 units, respectively.

\section{Table 8}

Material flow among machines (Problem M1)

\begin{tabular}{|c|c|c|c|c|c|c|c|c|c|c|c|c|c|c|c|c|c|c|c|c|}
\hline & $1-1$ & $1-2$ & $1-3$ & $1-4$ & $1-5$ & $1-6$ & $2-1$ & $2-2$ & $2-3$ & $2-4$ & $2-5$ & $2-6$ & $2-7$ & $3-1$ & $3-2$ & $3-3$ & $3-4$ & $3-5$ & $3-6$ & 3-7 \\
\hline $1-1$ & 0 & 5 & 0 & 0 & 0 & 0 & 0 & 0 & 0 & 0 & 0 & 0 & 1 & 0 & 0 & 0 & 0 & 0 & 0 & 0 \\
\hline $1-2$ & & 0 & 2 & 0 & 2 & 0 & 0 & 1 & 1 & 0 & 0 & 0 & 0 & 0 & 0 & 0 & 0 & 0 & 0 & 0 \\
\hline $1-3$ & & & 0 & 3 & 0 & 1 & 0 & 0 & 1 & 0 & 0 & 0 & 0 & 0 & 0 & 0 & 1 & 0 & 0 & 0 \\
\hline $1-4$ & & & & 0 & 1 & 0 & 0 & 0 & 0 & 0 & 0 & 0 & 1 & 1 & 0 & 0 & 0 & 0 & 0 & 0 \\
\hline $1-5$ & & & & & 0 & 0 & 0 & 1 & 0 & 0 & 0 & 0 & 0 & 1 & 0 & 0 & 0 & 0 & 1 & 0 \\
\hline $1-6$ & & & & & & 0 & 0 & 0 & 0 & 0 & 0 & 0 & 0 & 0 & 0 & 0 & 0 & 1 & 0 & 0 \\
\hline $2-1$ & & & & & & & 0 & 2 & 2 & 1 & 0 & 0 & 0 & 0 & 0 & 0 & 0 & 0 & 0 & 0 \\
\hline $2-2$ & & & & & & & & 0 & 2 & 0 & 0 & 0 & 0 & 0 & 0 & 0 & 0 & 0 & 0 & 0 \\
\hline $2-3$ & & & & & & & & & 0 & 2 & 0 & 0 & 1 & 0 & 0 & 0 & 0 & 0 & 0 & 0 \\
\hline $2-4$ & & & & & & & & & & 0 & 2 & 0 & 0 & 0 & 0 & 0 & 0 & 0 & 0 & 1 \\
\hline $2-5$ & & & & & & & & & & & 0 & 3 & 1 & 0 & 0 & 0 & 0 & 0 & 0 & 0 \\
\hline $2-6$ & & & & & & & & & & & & 0 & 1 & 0 & 0 & 0 & 0 & 1 & 0 & 0 \\
\hline $2-7$ & & & & & & & & & & & & & 0 & 0 & 0 & 0 & 0 & 0 & 0 & 0 \\
\hline $3-1$ & & & & & & & & & & & & & & 0 & 3 & 0 & 0 & 0 & 2 & 0 \\
\hline $3-2$ & & & & & & & & & & & & & & & 0 & 1 & 0 & 0 & 1 & 0 \\
\hline $3-3$ & & & & & & & & & & & & & & & & 0 & 3 & 1 & 0 & 0 \\
\hline $3-4$ & & & & & & & & & & & & & & & & & 0 & 2 & 0 & 1 \\
\hline $3-5$ & & & & & & & & & & & & & & & & & & 0 & 0 & 1 \\
\hline $3-6$ & & & & & & & & & & & & & & & & & & & 0 & 0 \\
\hline 3-7 & & & & & & & & & & & & & & & & & & & & 0 \\
\hline
\end{tabular}

\section{Table 9}

Material flow among machines (Problem M2)

\begin{tabular}{|c|c|c|c|c|c|c|c|c|c|c|c|c|c|c|c|c|c|c|c|c|}
\hline & $1-1$ & $1-2$ & $1-3$ & $1-4$ & $1-5$ & $2-1$ & $2-2$ & $2-3$ & $2-4$ & $2-5$ & $2-6$ & $2-7$ & 3-1 & 3-2 & $3-3$ & 3-4 & 3-5 & 4-1 & $4-2$ & 4-3 \\
\hline $1-1$ & 0 & 2 & 2 & 5 & 0 & 1 & 0 & 0 & 1 & 0 & 0 & 0 & 0 & 0 & 0 & 0 & 0 & 0 & 0 & 0 \\
\hline $1-2$ & & 0 & 0 & 0 & 3 & 0 & 0 & 0 & 1 & 0 & 0 & 0 & 1 & 0 & 1 & 0 & 0 & 0 & 0 & 0 \\
\hline $1-3$ & & & 0 & 0 & 1 & 1 & 0 & 0 & 0 & 0 & 0 & 0 & 0 & 0 & 0 & 0 & 0 & 1 & 0 & 1 \\
\hline $1-4$ & & & & 0 & 0 & 0 & 0 & 1 & 0 & 0 & 0 & 0 & 0 & 0 & 0 & 0 & 0 & 0 & 0 & 0 \\
\hline $1-5$ & & & & & 0 & 0 & 0 & 1 & 0 & 0 & 0 & 0 & 0 & 0 & 0 & 0 & 0 & 0 & 0 & 1 \\
\hline $2-1$ & & & & & & 0 & 2 & 0 & 2 & 0 & 0 & 0 & 0 & 0 & 0 & 0 & 0 & 0 & 0 & 0 \\
\hline $2-2$ & & & & & & & 0 & 0 & 2 & 1 & 0 & 0 & 0 & 0 & 0 & 0 & 0 & 0 & 0 & 0 \\
\hline $2-3$ & & & & & & & & 0 & 1 & 0 & 1 & 1 & 0 & 0 & 0 & 0 & 0 & 0 & 0 & 0 \\
\hline $2-4$ & & & & & & & & & 0 & 2 & 0 & 0 & 0 & 0 & 0 & 0 & 0 & 0 & 0 & 0 \\
\hline $2-5$ & & & & & & & & & & 0 & 2 & 0 & 0 & 0 & 0 & 1 & 0 & 0 & 0 & 0 \\
\hline $2-6$ & & & & & & & & & & & 0 & 3 & 0 & 0 & 0 & 0 & 0 & 0 & 0 & 0 \\
\hline $2-7$ & & & & & & & & & & & & 0 & 0 & 0 & 0 & 0 & 1 & 0 & 0 & 0 \\
\hline $3-1$ & & & & & & & & & & & & & 0 & 0 & 0 & 0 & 1 & 0 & 0 & 0 \\
\hline $3-2$ & & & & & & & & & & & & & & 0 & 3 & 0 & 1 & 0 & 1 & 0 \\
\hline $3-3$ & & & & & & & & & & & & & & & 0 & 1 & 2 & 0 & 0 & 0 \\
\hline $3-4$ & & & & & & & & & & & & & & & & 0 & 1 & 0 & 0 & 0 \\
\hline 3-5 & & & & & & & & & & & & & & & & & 0 & 0 & 0 & 0 \\
\hline 4-1 & & & & & & & & & & & & & & & & & & 0 & 1 & 2 \\
\hline $4-2$ & & & & & & & & & & & & & & & & & & & 0 & 3 \\
\hline $4-3$ & & & & & & & & & & & & & & & & & & & & 0 \\
\hline
\end{tabular}


Each of solutions reported by Adil \& Rajamani(2000) and Harhalakis et al. (1990) are studied under two cases. In M1-1 and M2-1, the layout of machines within all cells is single row (linear), and in M1-2 and M2-2 it is multi rows. The solutions of these cases have been summarized in Table 10.The problems were solved with good optimality gap and the results show that M1-2 gives the smallest material handling cost.

The next medium scale problem, M3 has been selected from Ramabhatta and Nagi (1996), they specified 4 machine cells with 1, 6, 6 and 2 machines in the cells 1-4 respectively. They developed a CMS model to minimize the number of inter-cell material flow instead of the inter-cell material handling cost, and finally it was realized that the total number of inter-cell movements is 83 . Now this problem is solved by the IFLP (considering inter and intra-cell material handling cost). It is assumed that the unit inter and intra-cell handling cost per unit distance are 7 and 5 units, respectively, also width of the aisle distance is assumed 0.5 units. M3 is studied under two cases, linear intra-cell layout (M3-1) and multi row intra-cell layout (M3-2). Table 10 shows the optimum solutions for M3-1 and M3-2. Both cases were solved optimally and finally it was concluded that in this problem multi row layout is better than linear layout with a gap of $10 \%$.

\section{Table 10}

The computational results of medium scale problems

\begin{tabular}{|c|c|c|c|c|c|c|c|c|}
\hline Problem & Source & Size & Intra-cell layout & $\begin{array}{l}\text { Coordinates of } \\
\text { cells }\end{array}$ & $\begin{array}{l}\text { Cells } \\
\text { orientation }\end{array}$ & $\begin{array}{l}\text { Objective } \\
\text { value }\end{array}$ & $\begin{array}{l}\text { CPU time } \\
\text { (s) }\end{array}$ & $\begin{array}{l}\text { Relative } \\
\text { gap }\end{array}$ \\
\hline M1-1 & $\begin{array}{l}\text { Adil \& Rajamani } \\
(2000)\end{array}$ & $3 \times 20$ & $\begin{array}{l}\text { Cell 1: 1-6 1-3 1-4 1-1 1-2 } 1-5 \\
\text { Cell 2: 2-6 2-5 2-7 2-4 2-3 2-2 2-1 } \\
\text { Cell 3: 3-5 3-4 3-3 3-7 3-2 3-1 3-6 }\end{array}$ & $\begin{array}{l}\text { Cell 1: }(1,0) \\
\text { Cell 2: }(0,0.5) \\
\text { Cell 3: }(2,0.5)\end{array}$ & $\begin{array}{l}\text { Cell 1: vertical } \\
\text { Cell 2: vertical } \\
\text { Cell 3: vertical }\end{array}$ & 1020 & 1897.343 & $0 \%$ \\
\hline M1-2 & $\begin{array}{l}\text { Adil \& Rajamani } \\
(2000)\end{array}$ & $3 \times 20$ & \begin{tabular}{llll}
\multicolumn{3}{l}{ Cell $1:$} & \\
$1-1$ & $1-2$ & $1-5$ & \\
$1-6$ & $1-3$ & $1-4$ & \\
Cell & $2:$ & & \\
$2-6$ & $2-5$ & $2-7$ & $2-2$ \\
$*$ & $2-4$ & $2-3$ & $2-1$ \\
Cell & $3:$ & & \\
$3-7$ & $3-4$ & $3-1$ & $3-6$ \\
$3-5$ & $3-3$ & $3-2$ & $*$ \\
\end{tabular} & $\begin{array}{l}\text { Cell 1: }(2.5,2) \\
\text { Cell 2: }(0,1) \\
\text { Cell 3: }(3,0)\end{array}$ & $\begin{array}{l}\text { Cell 1: } \\
\text { horizontal } \\
\text { Cell 2: vertical } \\
\text { Cell 3: } \\
\text { horizontal }\end{array}$ & 965 & $6457.313^{* *}$ & $28.74 \%$ \\
\hline M2-1 & $\begin{array}{l}\text { Harhalakis et al. } \\
\text { (1990) }\end{array}$ & $4 \times 20$ & $\begin{array}{lllllll}\text { Cell 1: } & & & & & \\
\text { 1-2 } & 1-5 & 1-4 & 1-1 & 1-3 & & \\
\text { Cell } 2 \text { : } & & & & & \\
2-7 & 2-6 & 2-3 & 2-5 & 2-4 & 2-1 & 2-2 \\
\text { Cell } 3: & & & & & \\
3-1 & 3-5 & 3-3 & 3-2 & 3-4 & & \\
\text { Cell } & 4: & & & & & \\
4-2 & 4-3 & 4-1 & & & & \\
\end{array}$ & $\begin{array}{l}\text { Cell 1: }(2,2) \\
\text { Cell 2: }(1,2) \\
\text { Cell 3: }(0,0) \\
\text { Cell 4: }(3,2)\end{array}$ & $\begin{array}{l}\text { Cell 1: vertical } \\
\text { Cell 2: vertical } \\
\text { Cell 3: vertical } \\
\text { Cell 4: vertical }\end{array}$ & 1075 & $9702.79 * *$ & $9.93 \%$ \\
\hline M2-2 & $\begin{array}{l}\text { Harhalakis et } \\
\text { al.(1990) }\end{array}$ & $4 \times 20$ & $\begin{array}{llll}\text { Cell } 1: & \\
1-5 & 1-3 & * \\
1-2 & 1-1 & 1-4 \\
\text { Cell } & 2: & \\
* & 2-6 & 2-7 & 2-3 \\
2-2 & 2-5 & 2-1 & 2-4 \\
\text { Cell } 3: & & \\
3-4 & 3-5 & 3-1 & \\
* & 3-3 & 3-2 & \\
\text { Cell } & 4: & & \\
4-2 & 4-3 & 4-1 & \\
\end{array}$ & $\begin{array}{l}\text { Cell 1: }(3,1.5) \\
\text { Cell 2: }(0,2) \\
\text { Cell 3: }(0.5,0) \\
\text { Cell 4: }(4.5,0.5)\end{array}$ & $\begin{array}{l}\text { Cell 1: vertical } \\
\text { Cell 2: } \\
\text { horizontal } \\
\text { Cell 3: } \\
\text { horizontal } \\
\text { Cell 4: vertical }\end{array}$ & 975 & $6346.16^{* *}$ & $32.17 \%$ \\
\hline M3-1 & $\begin{array}{l}\text { Ramabhatta \& } \\
\text { Nagi (1996) }\end{array}$ & $4 \times 15$ & $\begin{array}{l}\text { Cell 1: 1-1 } \\
\text { Cell 2: } 2-4 \text { 2-5 2-3 2-1 } 2-6 \text { 2-2 } \\
\text { Cell 3: 3-3 3-5 3-4 3-2 3-1 3-6 } \\
\text { Cell 4: } 4-2 \text { 4-1 }\end{array}$ & $\begin{array}{l}\text { Cell 1: }(1.5,5) \\
\text { Cell 2: }(1.5,1) \\
\text { Cell 3: }(0,2) \\
\text { Cell 4: }(3,0)\end{array}$ & $\begin{array}{l}\text { Cell 1: } \\
\text { horizontal } \\
\text { Cell 2: vertical } \\
\text { Cell 3: vertical } \\
\text { Cell 4: vertical } \\
\end{array}$ & 5192.5 & 215.678 & $0 \%$ \\
\hline M3-1 & $\begin{array}{l}\text { Ramabhatta \& } \\
\text { Nagi (1996) }\end{array}$ & $4 \times 15$ & 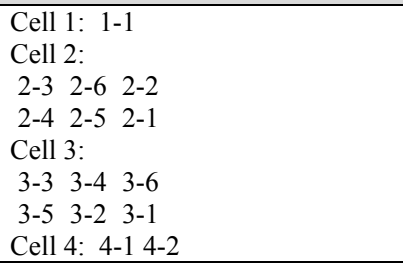 & $\begin{array}{l}\text { Cell 1: }(2.5,3) \\
\text { Cell 2: }(2,0.5) \\
\text { Cell 3: }(4.5,0.5) \\
\text { Cell 4: }(0,0)\end{array}$ & $\begin{array}{l}\text { Cell 1: } \\
\text { horizontal } \\
\text { Cell 2: vertical } \\
\text { Cell 3: vertical } \\
\text { Cell 4: vertical }\end{array}$ & 4657.5 & 1605.90 & $0 \%$ \\
\hline
\end{tabular}

* Empty candidate point

**Terminated by the solver due to insufficient physical memory 


\subsection{Large scale problems}

The first large scale problem has been selected from Kazerooni et al. (1997), they specified 7 machine cells with 4, 2, 2, 4, 5, 4 and 3 machines in the cells 1-7, respectively. To see the data sets, including processing routes and demand of parts, in order to specify material flow among machines, refer to Kazerooni et al. (1997). The unit intra and inter-cell material handling cost per unit distance are assumed 5 and 10 units, respectively; also the aisle distance is assumed 0.5 units. This problem has been solved in two conditions, in the first condition i.e. L1-1, the layout of machines within all cells is single row and in the next one i.e. L1-2 the layout of machines in cells 1, 4, 5 and 6 are multi rows and in the remaining cells are single row. The optimum layout of L1-1 and L1-2 has been presented in Table 12. L1-1 was interrupted after 10000 seconds, while L1-2 was terminated by the solver due to insufficient physical memory after 3927 seconds. Amount of material handling cost for L1-1 (i.e. single row layout) is 79910 with an optimality gap of $9.19 \%$; while for L1-2 it is 77385 with an optimality gap of $28.98 \%$. Therefore, it is concluded that for the problem presented by Kazerooni et al. (1997), the multi rows layout is better than single row layout. The next large scale problems (L2 and L3) have been selected from Chan et al. (2006). They studied a two stage CMS problem on an industrial case with 37 machines and 30 parts, where the machine cells and part families are formed in the first stage, and cell sequencing is established in the second stage. They founded two different solutions for their problem (see Table 11) and investigated different cells sequence in order to find the best sequence of the cells how total intercellular part movement being minimized. Finally, they realized that the optimal objective value for the both solutions is equal to 21 .

\section{Table 11}

Presented machine cells by Chan et al. (2006) as well as machine indexes used in this paper

\begin{tabular}{llll}
\hline Problem & Cell number & Machines (Source paper) & Machines (This paper) \\
\hline L2 & 1 & $3,4,15,19,24,34,35,36,37$ & $1-1,1-2,1-3,1-4,1-5,1-6,1-7,1-8,1-9$ \\
& 2 & $7,8,9,10,11,12,13,16,18,20,21,26,31$ & $2-1,2-2,2-3,2-4,2-5,2-6,2-7,2-8,2-9,2-10,2-11,2-12,2-13$ \\
& 3 & $14,17,22,27,28,29,30$ & $3-1,3-2,3-3,3-4,3-5,3-6,3-7$ \\
& 4 & $1,2,5,6,23,25,32,33$ & $4-1,4-2,4-3,4-4,4-5,4-6,4-7,4-8$ \\
\hline L3 & 1 & $1,5,14,17,22,29,30$ & $1-1,1-2,1-3,1-4,1-5,1-6,1-7$ \\
& 2 & $3,4,15,19,24,34,35,36,37$ & $2-1,2-2,2-3,2-4,2-5,2-6,2-7,2-8,2-9$ \\
& 3 & $2,6,23,25,27,28,32,33$ & $3-1,3-2,3-3,3-4,3-5,3-6,3-7,3-8$ \\
& 4 & $7,8,9,10,11,12,13,16,18,20,21,26,31$ & $4-1,4-2,4-3,4-4,4-5,4-6,4-7,4-8,4-9,4-10,4-11,4-12,4-13$ \\
\hline
\end{tabular}

\section{Table 12}

The computational results of large scale problems

\begin{tabular}{|c|c|c|c|c|c|c|c|c|c|c|}
\hline Problem & Source & Size & & Intra-ce & layout & $\begin{array}{l}\text { Coordinates of } \\
\text { cells }\end{array}$ & Cells orientation & $\begin{array}{l}\text { Objective } \\
\text { value }\end{array}$ & CPU time (s) & $\begin{array}{l}\text { Relative } \\
\text { Gap }\end{array}$ \\
\hline L1-1 & $\begin{array}{l}\text { Kazerooni } \\
\text { et al. } \\
(1997)\end{array}$ & $7 \times 24$ & $\begin{array}{l}\text { Cell 1: } 1-4 \text { 1-3 } 1-2 \text { 1-1 } \\
\text { Cell 2: 2-2 } 2-1 \\
\text { Cell 3: 3-2 3-1 } \\
\text { Cell 4: 4-1 4-2 4-3 4-4 }\end{array}$ & & $\begin{array}{l}\text { Cell 5: 5-5 5-4 5-3 5-2 5-1 } \\
\text { Cell 6: 6-1 6-2 6-3 6-4 } \\
\text { Cell 7: 7-3 7-2 7-1 }\end{array}$ & $\begin{array}{l}\text { Cell 1: }(2,7.5) \\
\text { Cell 2: }(3.5,5.5) \\
\text { Cell 3: }(6.5,4.5) \\
\text { Cell 4: }(0,6) \\
\text { Cell 5: }(5,5) \\
\text { Cell 6: }(2,3.5) \\
\text { Cell 7: }(5,1.5)\end{array}$ & $\begin{array}{l}\text { Cell 1: horizontal } \\
\text { Cell 2: Vertical } \\
\text { Cell 3: Vertical } \\
\text { Cell 4: horizontal } \\
\text { Cell 5: Vertical } \\
\text { Cell 6: horizontal } \\
\text { Cell 7: horizontal }\end{array}$ & 79910 & 10000 & $9.19 \%$ \\
\hline L1-2 & $\begin{array}{l}\text { Kazerooni } \\
\text { et al. } \\
(1997)\end{array}$ & $7 \times 24$ & $\begin{array}{ccc}\text { Cell 1: } & 1-3 & 1-2 \\
& 1-3 & 1-2 \\
\text { Cell 2: } & 2-2 & 2-1 \\
\text { Cell 3: } & 3-2 & 3-1 \\
\text { Cell 4: } & 4-1 & 4-4 \\
& 4-2 & 4-3\end{array}$ & & 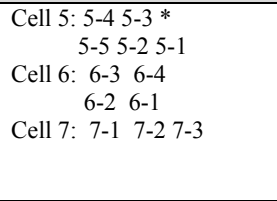 & $\begin{array}{l}\text { Cell 1: }(0,11.5) \\
\text { Cell 2: }(2.5,7.5) \\
\text { Cell 3: }(4,7.5) \\
\text { Cell 4: }(0,9) \\
\text { Cell 5: }(5,5) \\
\text { Cell 6: }(0.5,6.5) \\
\text { Cell 7: }(2.5,4.5)\end{array}$ & $\begin{array}{l}\text { Cell 1: Vertical } \\
\text { Cell 2: Vertical } \\
\text { Cell 3: Vertical } \\
\text { Cell 4: horizontal } \\
\text { Cell 5: Horizontal } \\
\text { Cell 6: Vertical } \\
\text { Cell 7: Vertical }\end{array}$ & 77385 & $3427.88^{* *}$ & $26.36 \%$ \\
\hline $\mathrm{L} 2$ & $\begin{array}{l}\text { Chan et } \\
\text { al. }(2006)\end{array}$ & $4 \times 37$ & $\begin{array}{llll}\text { Cell 1: } & & \\
1-3 & 1-8 & 1-1 & \\
1-2 & 1-5 & 1-6 & \\
1-4 & 1-9 & 1-7 & \\
\text { Cell } & 2 \text { : } \\
2-3 & 2-9 & 2-11 & 2-7 \\
2-8 & 2-2 & 2-5 & 2-6 \\
2-1 & 2-12 & * & *\end{array}$ & $\begin{array}{c} \\
2-10 \\
2-4 \\
2-13\end{array}$ & 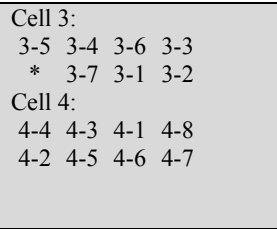 & $\begin{array}{l}\text { Cell 1: }(3,7.5) \\
\text { Cell 2: }(4,4) \\
\text { Cell 3: }(2.5,0) \\
\text { Cell 4: }(0,4.5)\end{array}$ & $\begin{array}{l}\text { Cell 1: vertical } \\
\text { Cell 2: horizontal } \\
\text { Cell 3: vertical } \\
\text { Cell 4: vertical }\end{array}$ & 182 & $7123.63 * *$ & $58.35 \%$ \\
\hline $\mathrm{L} 3$ & $\begin{array}{l}\text { Chan et } \\
\text { al. (2006) }\end{array}$ & $4 \times 37$ & $\begin{array}{rccc}\text { Cell 1: } & 1-1 & 1-7 & 1-8 \\
& 1-4 & 1-6 & 1-3 \\
& 1-2 & 1-5 & 1-0 \\
\text { Cell 2: } & * & 2-4 & 2-7 \\
2-13 & 2-9 & 2-11 \\
2-10 & 2-2 & 2-6 & 2-\end{array}$ & $\begin{array}{l} \\
\\
2-5 * \\
2-122-3 \\
82-1\end{array}$ & 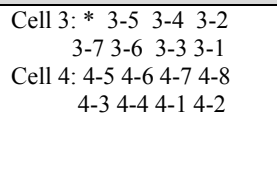 & $\begin{array}{l}\text { Cell 1: }(4.5,4) \\
\text { Cell 2: }(0,4) \\
\text { Cell 3: }(1.5,1) \\
\text { Cell 4: }(5,0)\end{array}$ & $\begin{array}{l}\text { Cell 1: horizontal } \\
\text { Cell 2: horizontal } \\
\text { Cell 3: horizontal } \\
\text { Cell 4: vertical }\end{array}$ & 184 & $6151.80^{* *}$ & $55.32 \%$ \\
\hline
\end{tabular}

* Empty candidate point ${ }^{* *}$ Terminated by the solver due to insufficient physical memory 
Now the IFLP is imployed to solve the proposed problem by Chan et al. (2006). It is assumed that the unit inter and intra-cell material handling cost per unit distance is 2 and 1 units, respectively, also the aisle distance is assumed 0.5 units.

L2 and L3 were solved and the results have been illustrated in Table 12. Unfortunately, these problems have not been solved with good optimality gap and the relative gaps are $58.35 \%$ and $55.32 \%$ for L2 and L3, respectively. However, the primary results almost support the equality of L2 and L3, which was reported by Chan et al. (2006).

\section{A heuristic method for large scale problems}

In order to solve large scale problems in a short amount of time, a heuristic method have been developed. In this heuristic method, the integrated model is decomposed into three sub models. The first submodel (Model F1) creates a primary department layout, the second one (Model F2) uses the outputs of Model F1 to assign facilities to the existent department layout, then the third model (Model F3) uses the outputs of Model F2 to re-design the department layout and improve the inter-department material handling costs. Again, model F2 is implemented to re-assign facilities to the existence layout, in order to minimize total material handling costs. This procedure between Model F2 and Model F3 continues, until no further improvement resulted in the objective function. The stages of proposed heuristic are explained in detail in the next stages.

\subsection{Stage 1}

In this stage, a primary department layout is created according to the following MIP model.

Model F1:

$\operatorname{Min} \sum_{i} \sum_{j>i} F C_{i j}\left(d x_{i j}^{+}+d x_{i j}^{-}+d y_{i j}^{+}+d y_{i j}^{-}\right)$

subject to: (30)-(33) and (36)-(38)

$x_{i}-x_{j}=d x_{i j}^{+}-d x_{i j}^{-}, \quad \forall j>i$,

$y_{i}-y_{j}=d y_{i j}^{+}-d y_{i j}^{-}, \quad \forall j>i$,

$d x_{i j}^{+}, d x_{i j}^{-}, d y_{i j}^{+}, d y_{i j}^{-} \geq 0, \quad \forall j>i$,

In the above model, $F C_{i j}$ is total material flow cost between department $i$ and department $j$, and is calculated as follows: $F C_{i j}=\sum_{k=1}^{M_{i}} \sum_{l=1}^{M_{j}} f_{i j k l} \cdot c_{i j k l}$; also $d x_{i j}^{+}+d x_{i j}^{-}$and $d y_{i j}^{+}+d y_{i j}^{-}$measure the horizontal and vertical distances between department $i$ and department $j$, respectively, all remaining parameters are the same before defined. After solving Model F1, total material handling cost is set to $T C=\infty$ and the solutions i.e. $\tilde{x}_{i}, \tilde{y}_{i}$ and $\tilde{u}_{i}$ are placed as the inputs of the next model (Model F2).

\subsection{Stage 2}

In this stage, facilities are arranged within the existent department layout according to the following MIP model.

Model F2:

$\min T C_{2}=(19)$ 
subject to:(20)-(23), (26)-(29), (34) and (39)-(41)

$$
\begin{gathered}
\tilde{x}_{i}-\tilde{x}_{j}+\frac{-w_{i}+\tilde{u}_{i}\left(w_{i}-h_{i}\right)+w_{j}-\tilde{u}_{j}\left(w_{j}-h_{j}\right)}{2}+\left(1-\tilde{u}_{i}\right) \sum_{m=1}^{C o_{i}} z_{i k m}^{X} \cdot a_{i m}+\tilde{u}_{i} \sum_{n=1}^{R o_{i}} z_{i k n}^{Y} \cdot b_{i n} \\
-\left(1-\tilde{u}_{j}\right) \sum_{m=1}^{C o_{j}} z_{j l m}^{X} \cdot a_{j m}-\tilde{u}_{j} \sum_{n=1}^{R o_{j}} z_{j l n}^{Y} \cdot b_{j n}=d x_{i j k l}^{+}-d x_{i j k l}^{-}, \quad i=1, \ldots, C, \\
j=i+1, \ldots, C, \quad k=1, \ldots, M_{i}, \quad l=1, \ldots, M_{j} \\
\tilde{y}_{i}-\tilde{y}_{j}+\frac{-h_{i}+\tilde{u}_{i}\left(h_{i}-w_{i}\right)+h_{j}-\tilde{u}_{j}\left(h_{j}-w_{j}\right)}{2}+\tilde{u}_{i} \sum_{m=1}^{C o_{i}} z_{i k m}^{X} \cdot a_{i m}+\left(1-\tilde{u}_{i}\right) \sum_{n=1}^{R o_{i}} z_{i k n}^{Y} \cdot b_{i n} \\
-\tilde{u}_{j} \sum_{m=1}^{C o_{j}} z_{j l m}^{X} \cdot a_{j m}-\left(1-\tilde{u}_{j}\right) \sum_{n=1}^{R o_{j}} z_{j l n}^{Y} \cdot b_{j n}=d y_{i j k l}^{+}-d y_{i j k l}^{-}, \quad i=1, \ldots, C, \\
j=i+1, \ldots, C, \quad k=1, \ldots, M_{i}, \quad l=1, \ldots, M_{j}
\end{gathered}
$$

where $\tilde{x}_{i}, \tilde{y}_{i}$ and $\tilde{u}_{i}$ represent existent department layout (obtained by Model F1 or the next model i.e. Model F3). After solving Model F2, if the resulted objective value i.e.TC $C_{2}$ becomes better than current objective value i.e. $T C$ then $T C=T C_{2}$ and the main outputs of Model F2 i.e. $\tilde{z}_{i k n}^{X}, \tilde{z}_{i k n}^{Y}$, are placed as the inputs of Model F3, otherwise the procedure is terminated.

\subsection{Stage 3}

In this stage the department layout are re-designed according to Model F3; in fact this model changes the position and orientation of departments in order to improve the inter-department material handling cost. In this submodel there are eight states for each department with respect to other departments that must be considered in the mathematical model, these states have been illustrated in Fig. 2.
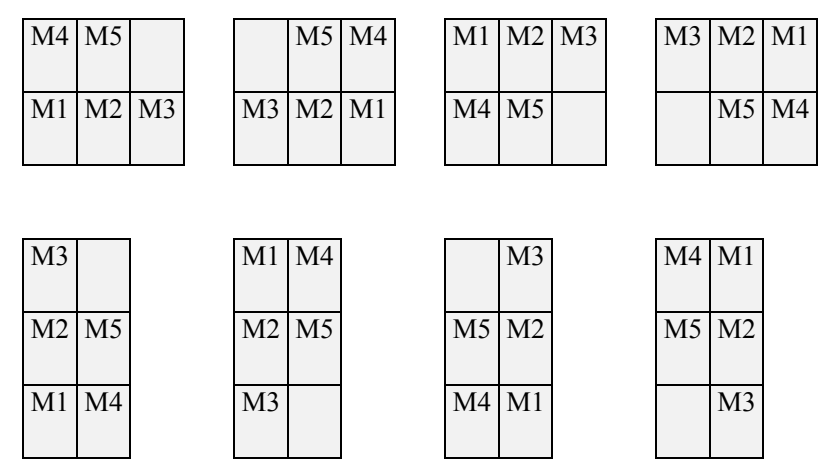

Fig. 2. Eight possible states for placing a department, considering layout of facilities within the department

After applying standard linearization methods Model F3 is formulated as the following MIP model:

Model F3:

$\min T C_{3}=\sum_{i=1}^{C-1} \sum_{j=i+1}^{C} \sum_{k=1}^{M_{i}} \sum_{l=1}^{M_{j}} f_{i j k l} . c_{i j k l}\left(d x_{i j k l}^{+}+d x_{i j k l}^{-}+d y_{i j k l}^{+}+d y_{i j k l}^{-}\right)+T C^{\text {Intra }}$ 
subject to: (30-(34) and (36)-(38)

$$
\begin{aligned}
& x_{i}-\left(1-u_{i}\right) \frac{w_{i}}{2}-u_{i} \frac{h_{i}}{2}+A_{i k}+\mu_{i}^{l}\left(h_{i}-2 B_{i k}+2 A_{i k}-w_{i}\right)+u_{i}^{l}\left(w_{i}-2 A_{i k}\right) \\
& +u_{i}\left(B_{i k}-A_{i k}\right)-x_{j}+\left(1-u_{j}\right) \frac{w_{j}}{2}+u_{j} \frac{h_{j}}{2}-A_{j l}-\mu_{j}^{l}\left(h_{j}-2 B_{j l}+2 A_{j l}-w_{j}\right) \\
& -u_{j}^{l}\left(w_{j}-2 A_{j l}\right)-u_{j}\left(B_{j l}-A_{j l}\right)=d x_{i j k l}^{+}-d x_{i j k l}^{-}, \quad i=1, \ldots, C \text {, } \\
& j=i+1, \ldots, C, \quad k=1, \ldots, M_{i}, \quad l=1, \ldots, M_{j} \\
& y_{i}-\left(1-u_{i}\right) \frac{h_{i}}{2}-u_{i} \frac{w_{i}}{2}+B_{i k}+\mu_{i}^{u}\left(2 B_{i k}-h_{i}-2 A_{i k}+w_{i}\right)+u_{i}^{u}\left(h_{i}-2 B_{i k}\right) \\
& +u_{i}\left(A_{i k}-B_{i k}\right)-y_{i}+\left(1-u_{i}\right) \frac{h_{i}}{2}+u_{i} \frac{w_{i}}{2}-B_{j l}-\mu_{j}^{u}\left(2 B_{j l}-h_{j}-2 A_{j l}+w_{j}\right) \\
& -u_{j}^{u}\left(h_{j}-2 B_{j l}\right)-u_{j}\left(A_{j l}-B_{j l}\right)=d y_{i j k l}^{+}-d y_{i j k l}^{-}, \quad i=1, \ldots, C \text {, } \\
& j=i+1, \ldots, C, \quad k=1, \ldots, M_{i}, \quad l=1, \ldots, M_{j} \\
& \mu_{i}^{l} \leq u_{i}, \quad i=1, \ldots, C \\
& \mu_{i}^{l} \leq u_{i}^{l}, \quad i=1, \ldots, C \\
& \mu_{i}^{l} \geq u_{i}^{l}+u_{i}-1, \quad i=1, \ldots, C \\
& \mu_{i}^{u} \leq u_{i}, \quad i=1, \ldots, C \\
& \mu_{i}^{u} \leq u_{i}^{u}, \quad i=1, \ldots, C \\
& \mu_{i}^{u} \geq u_{i}^{u}+u_{i}-1, \quad i=1, \ldots, C \\
& \mu_{i}^{l}, \mu_{i}^{u} \geq 0, \quad i=1, \ldots, C
\end{aligned}
$$

\begin{tabular}{|c|c|c|c|c|c|c|}
\hline States & $u_{i}$ &  & & $u_{i}^{u}$ & width & height \\
\hline 1 & & 0 & 0 & 0 & $x_{i}-\frac{w_{i}}{2}+\tilde{A}_{i k}$ & $y_{i}-\frac{h_{i}}{2}+\tilde{B}_{i k}$ \\
\hline 2 & & 0 & 0 & 1 & $x_{i}-\frac{w_{i}}{2}+\tilde{A}_{i k}$ & $y_{i}+\frac{h_{i}}{2}-\tilde{B}_{i k}$ \\
\hline 3 & & 0 & 1 & 0 & $x_{i}+\frac{w_{i}}{2}-\tilde{A}_{i k}$ & $y_{i}-\frac{h_{i}}{2}+\tilde{B}_{i k}$ \\
\hline 4 & & 0 & 1 & 1 & $x_{i}+\frac{w_{i}}{2}-\tilde{A}_{i k}$ & $y_{i}+\frac{h_{i}}{2}-\tilde{B}_{i k}$ \\
\hline 5 & & 1 & 0 & 0 & $x_{i}-\frac{h_{i}}{2}+\tilde{B}_{i k}$ & $y_{i}-\frac{\underline{w}_{i}}{2}+\tilde{A}_{i k}$ \\
\hline 6 & & 1 & 0 & 1 & $x_{i}-\frac{h_{i}}{2}+\tilde{B}_{i k}$ & $y_{i}+\frac{w_{i}}{2}-\tilde{A}_{i k}$ \\
\hline 7 & & 1 & 1 & 0 & $x_{i}+\frac{h_{i}}{2}-\tilde{B}_{i k}$ & $y_{i}-\frac{w_{i}}{2}+\tilde{A}_{i k}$ \\
\hline 8 & & 1 & 1 & 1 & $x_{i}+\frac{h_{i}}{2}-\tilde{B}_{i k}$ & $y_{i}+\frac{w_{i}}{2}-\tilde{A}_{i k}$ \\
\hline
\end{tabular}

Note that, since in Model F3 the layout of facilities within the departments is fixed therefore the intradepartment material handling cost is constant and it is calculated as follows: $T C^{\text {Intra }}=\sum_{i=1}^{C} \sum_{k=1}^{M_{i}-1} \sum_{l=k+1}^{M_{i}}\left(\left|A_{i k}-A_{i l}\right|+\left|B_{i k}-B_{i l}\right|\right), \quad$ where $\quad A_{i k}=\sum_{m=1}^{C o_{i}} \tilde{z}_{i k m}^{X} . a_{i m}, B_{i k}=$ $\sum_{n=1}^{R o_{i}} \tilde{z}_{i k n}^{Y} . b_{i n}$. Also in the above model $u_{i}, u_{i}^{l}$ and $u_{i}^{u}$ are related to the direction of departmenti. Table 13 illustrates the eight possible states resulted by these variables for a hypothetical facility within a department. After solving Model 3, if the resulted objective value i.e. $T C_{3}$ be better than current objective value i.e. $T C$ then $T C=T C_{3}$ and the main outputs of Model 3 i.e. $\tilde{z}_{i k n}^{X}, \tilde{z}_{i k n}^{Y}$, are placed as the inputs of Model F2, otherwise the procedure is terminated. Fig. 3. illustrates the flowchart of proposed heuristic method.

\section{Table 13}

The coordinates of a hypothetical facility within a department with respect to the direction of the department 


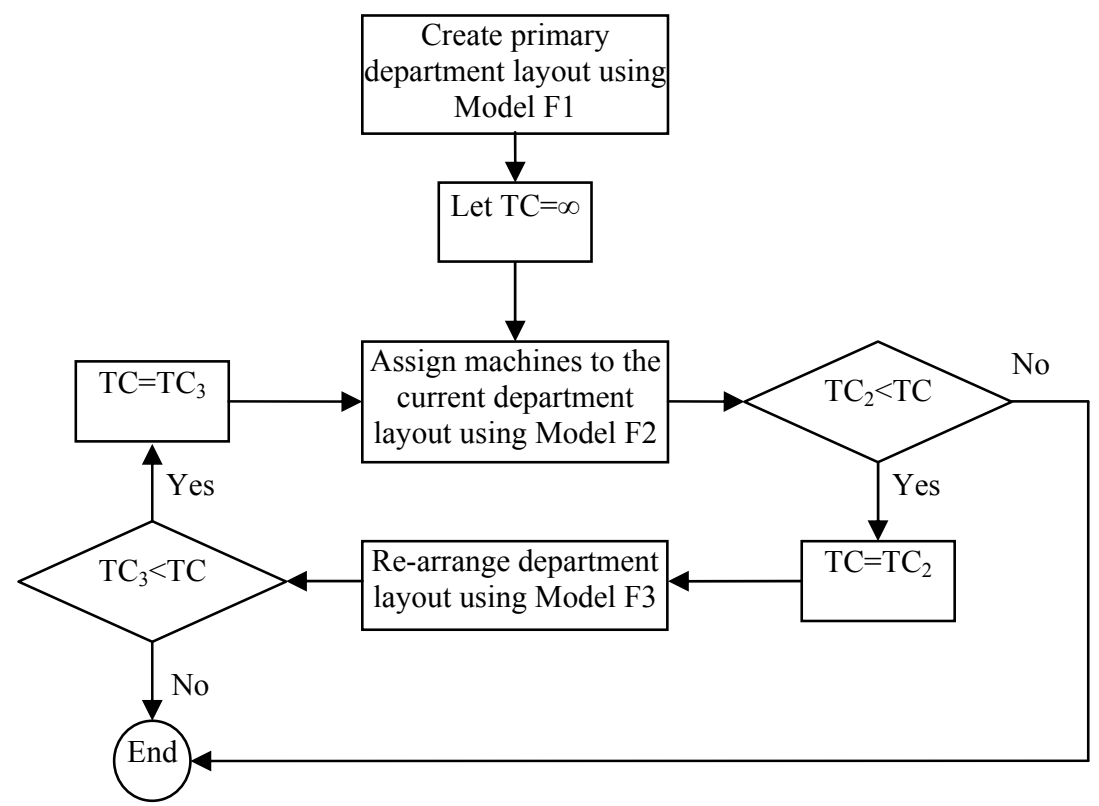

Fig. 3. Flowchart of proposed heuristic method

\section{Numerical example.3}

In this section, the proposed heuristic method is implemented to solve the same problems presented in section 5. The results are compared against the IFLP. The computational results have been summarized in Table 14. The column of resource time shows the maximum time for each iteration of the heuristic method. Also the error percent column 'Error (\%)'has been calculated as follows: $\left(\frac{O b j^{\text {Heuristic }}-O b j^{I F L P}}{O b j^{I F L P}}\right) \times 100$.

\section{Table 14}

The results of the heuristic method

\begin{tabular}{|c|c|c|c|c|c|c|c|c|}
\hline \multirow{2}{*}{ Problem } & \multicolumn{3}{|c|}{ IFLP } & \multicolumn{5}{|c|}{ Heuristic method } \\
\hline & Objective & $\begin{array}{l}\text { CPU time } \\
\text { (s) }\end{array}$ & $\begin{array}{l}\text { Gap } \\
(\%)\end{array}$ & $\begin{array}{c}\text { Resource } \\
\text { time (s) }\end{array}$ & CPU time (s) & Objective & No. iterations & $\begin{array}{l}\text { Error } \\
(\%)\end{array}$ \\
\hline $\mathrm{S} 1-1$ & 26779.6 & 2.140 & $0 \%$ & - & 1.246 & 26820 & 5 & $0.15 \%$ \\
\hline S1-2 & 25479.1 & 11.830 & $0 \%$ & - & 2.622 & 25479.1 & 5 & $0.00 \%$ \\
\hline $\mathrm{S} 1-3$ & 24444.3 & 14.743 & $0 \%$ & - & 3.495 & 24923.7 & 5 & $1.96 \%$ \\
\hline S2-1 & 32750 & 6.796 & $0 \%$ & - & 1.212 & 33986 & 5 & $3.77 \%$ \\
\hline S2-2 & 34430 & 29.322 & $0 \%$ & - & 1.922 & 34446 & 7 & $0.05 \%$ \\
\hline $\mathrm{S} 2-3$ & 42583 & 17.218 & $0 \%$ & - & 1.47 & 43343 & 5 & $1.78 \%$ \\
\hline M1-1 & 1020 & 1897.343 & $0 \%$ & - & 88.148 & 1020 & 5 & $0.00 \%$ \\
\hline M1-2 & 965 & $6457.313^{*}$ & $28.74 \%$ & - & 400.683 & 980 & 5 & $1.55 \%$ \\
\hline M2-1 & 1075 & $9702.79 *$ & $9.93 \%$ & - & 60.807 & 1060 & 8 & $-1.40 \%$ \\
\hline M2-2 & 975 & $6346.16^{*}$ & $32.17 \%$ & - & 759.338 & 1005 & 5 & $3.08 \%$ \\
\hline M3-1 & 5192.5 & 215.678 & $0 \%$ & - & 8.133 & 5257.5 & 3 & $1.25 \%$ \\
\hline M3-2 & 4657.5 & 1605.90 & $0 \%$ & - & 21.733 & 4657.5 & 5 & $0.00 \%$ \\
\hline L1-1 & 79910 & 10000 & $9.19 \%$ & 20 & 61.864 & 83155 & 6 & $4.06 \%$ \\
\hline L1-2 & 77385 & $3427.88^{*}$ & $26.36 \%$ & 20 & 67.346 & 77385 & 6 & $0 \%$ \\
\hline L2 & 182 & $7123.63^{*}$ & $58.35 \%$ & 60 & 254.329 & 172 & 7 & $-5.49 \%$ \\
\hline L3 & 180 & $6151.80 *$ & $55.32 \%$ & 100 & 566.802 & 175 & 6 & $-2.78 \%$ \\
\hline
\end{tabular}

\footnotetext{
* Interrupted by the solver due to insufficient physical memory
}

The results show that in cases of S1-2, M1-1, M3-2 and L1-2 the objective value of the proposed heuristic is equal to that of IFLP, and in cases of M2-1, L2, L3 the heuristic method even obtained better solution than the IFLP. Also in the remaining cases, the average error percent between the IFLP 
and heuristic method is about $2.2 \%$. Therefore, it is deduced that the proposed heuristic is an efficient method for solving problems in reasonable time.

\section{Conclusions}

In this paper, an integrated layout model was developed to incorporate inter and intra-department layout. First, a modified version of QAP, namely GRQAP, with fewer binary variables was developed; in contrast to traditional QAP, the GRQAP can solve the problems in a shorter computational time and with less physical memory. Then the IFLP was formulated based on the GRQAP in order to minimize total material handling cost. Several numerical examples were selected from the literature of CMS and the IFLP applied on them. Also due to the complexity of integrated model, an efficient heuristic method was developed in order to solve large scale problems in short amount of time. Finally, it was deduced that in contrast with the ICFLP, the proposed heuristic could even obtain better solution over a short amount of time.

\section{References}

Adel El-Baz, M. (2004). A genetic algorithm for facility layout problems of different manufacturing environments. Computers \& Industrial Engineering, 47, 233-246.

Adil, G. K., \& Rajamani, D. (2000). The Trade-Off Between intracell and intercell moves in group technology cell formation. Journal of Manufacturing Systems, 19 (5), 305-317.

Akturk, M. S., \& Turkcan, A. (2000). Cellular manufacturing system design using a holonistic approach. International Journal of Production Research, 38 (10), 2327-2347.

Chan, F. T., Lau, K., Chan, P., \& Choy, K. (2006). Two-stage approach for machine-part grouping and cell layout problems. Robotics and Computer-Integrated Manufacturing, 22, 217-238.

Cheng, C. H., Madan, M. S., \& Motwani, J. (1966). Knapsack-based algorithm for designing cellular manufacturing systems. The Journal of Operation Research Society, 47 (12), 1648-1476.

Chiang, C.-P., \& Lee, S.-D. (2004). Joint determination of machine cells and linear intercell layout. Computers \& Operations Research, 31, 1603-1619.

Commander, C. W. (2003). A Survey of the Quadratic Assignment Problem, with Applications. The University of Florida.

Drira, A., Pierreval, H., \& Hajri-Gabouj, S. (2007). Facility layout problems: A survey. Annual Reviews in Control, 31, 255-267.

Harhalakis, G., Nagi, R., \& Proth, J. M. (1990). An Eflicient Heuristic in Manufacturing Cell Formation for Group Technology Applications. International Journal of Prduction Research, 28 (1), 185-198.

Heragu, S. S., \& Kusiak, A. (1991). Effcient models for the facility layout problem. European Journal of Operational Research, 53, 1-13.

Heragu, S. S., \& Kusiak, A. (1988). Machine layout problem in flexible manufacturing systems. Operations Research, 36 (2), 258-268.

Hicks, C. (2006). A Genetic Algorithm tool for optimising cellular or functional layouts in the capital goods industry. International Journal of Production Economics, 104, 598-614.

Kaku, B., Thompson, G., \& Baybars, I. (1988). A heuristic method for the multi-story layout problem. European Journal of Operational Research, 37, 384-397.

Kaufmann, L., \& Broeckx, F. (1978). An algorithm for the quadratic assignment problem using Benders' decomposition. European Journal of Operational Research, 2, 204-211.

Kazerooni, M. L., Luong, H. S., \& Abhary, K. (1997). A genetic algorithm based cell design considering alternative routing. International Journal of Computational Integrated Manufacturing Systems, 10 (2), 93-107.

Kochhar, J. S., Foster, B. T., \& Heragu, S. S. (1998). A GENETIC ALGORITHM FOR THE UNEQUAL AREA FACILITY LAYOUT PROBLEM. Computers \& Operations Research, 25 (7/8), 583-594. 
Konak, A., Kulturel-Konak, S., Norman, B. A., \& Smith, A. E. (2006). Anewmixed integer programming formulation for facility layout design using flexible bays. Operations Research Letters, 34, $660-672$.

Koopmans, T. C., \& Beckmann, M. J. (1957). Assignment problems and the location of economic activities. Econometrica, 25, 53-76.

Kusiak, A., \& Heragu, S. (1987). The facility layout problem. European Journal of Operational Research, 29, 229-251.

Love, R., \& Wong, J. (1976). On solving a one-dimensional allocation problem with integer programming. Information Processing and Operations Research, 14 (2), 139-143.

Meller, R., \& Gau, K. (1996). The facility layout problem: recent and emerging trends and perspectives. Journal of Manufacturing Systems, 15, 351-366.

Ramabhatta, V., \& Nagi, R. (1996). An integrated formulation of manufacturing cell formation with capacity planning and multiple routings. Baltzer Journals, 1-18.

Sahni, S., \& Gonzalez, T. (1976). P-complete Approximation Problems. Journal of the ACM, 23, 555565.

Simmons, D. (1969). One-dimensional space allocation: An ordering algorithm. Operations Research, $17,812-826$.

Singh, S. P., \& Sharma, R. R. (2005). A review of different approaches to the facility layout problems. The International Journal of Advanced Manufacturing Technology, 30, 425-433.

Solimanpur, M., Vrat, P., \& Shankar, R. (2005). An ant algorithm for the single row layout problem in flexible manufacturing systems.Computers \& Operations Research, 3 (32), pp. 583-598.

Sule, D. R. (1994). Manufacturing facilities: location, planning, and design (2nd ed.). Boston: PWS Publishing Company.

Taghavi, A., \& Murat, A. (2011). A heuristic procedure for the integrated facility layout design and flow assignment problem. Computers \& Industrial Engineering, 61, 55-63.

Tavakkoli-Moghaddam, R., Javadian, N., Javadi, B., \& Safaei, N. (2007). Design of a facility layout problem in cellular manufacturing systems with stochastic demands. Applied Mathematics and Computation, 184, 721-728.

Tompkins, J. A., White, J. A., Bozer, Y. A., \& Tanchoco, J. M. (2003). Facilities planning (3rd ed.). New York: John Wiley \& Sons.

Wemmerlöv, U., \& Hyer, N. (1986). Procedures for the part family/machine group identification problem in cellular manufacture. Journal of Operations Management, 6, 125-147.

Wu, X., Chu, C.-H., Wang, Y., \& Yan, W. (2007). A genetic algorithm for cellular manufacturing design and layout. European Journal of Operational Research, 181, 156-167. 